\title{
Review Article \\ Potential of Traditional Knowledge of Plants in the Management of Arthropods in Livestock Industry with Focus on (Acari) Ticks
}

\author{
Wycliffe Wanzala ${ }^{1,2}$ \\ ${ }^{1}$ Department of Biological Sciences, School of Science and Information Sciences, Maasai Mara University, \\ P.O. Box 861-20500, Narok, Kenya \\ ${ }^{2}$ Behavioural and Chemical Ecology Department, International Centre of Insect Physiology and Ecology, \\ African Insect Science for Food and Health, P.O. Box 30772-00100-GPO, Nairobi, Kenya
}

Correspondence should be addressed to Wycliffe Wanzala; osundwal@yahoo.com

Received 19 December 2016; Accepted 11 May 2017; Published 17 July 2017

Academic Editor: José L. Rios

Copyright (C) 2017 Wycliffe Wanzala. This is an open access article distributed under the Creative Commons Attribution License, which permits unrestricted use, distribution, and reproduction in any medium, provided the original work is properly cited.

Antitick plants and related ethnoknowledge/ethnopractices with potential for integrated tick control and management strategies to improve livestock production are reviewed. About 231 plants reviewed showed a variety of bioactive properties, namely, being toxic, repellent, antifeedant, and antiovipositant and ability to immobilize target tick species. These ethnobotanical substances are potentially useful in developing sustainable, efficient, and effective antitick agents suitable for rural livestock farmers. Majority of these plants are holistic in action, economically affordable, user friendly, easily adaptable and accessible, and environmentally friendly and help develop community-driven tick control interventions well suited to local conditions and specific to different livestock communities. Such a multipurpose intervention best fits the recent ascendancy of individual livestock owners as the key players in tick control programmes, particularly following the withdrawal of subsidies accorded to tick control programmes by most African government agencies since mid-1980s. However, scientific validation of antitick ethnobotanicals on their efficacy and formulation of packages easily handled by local communities is necessary to achieve a significantly increased use of such remedies. It is envisaged that the results of validation may lead to the discovery of effective and affordable antitick products. The effectiveness of these "best bets" ethnopractices can be greatest, if they are appropriately blended with conventional technologies.

\section{Introduction}

Animals worldwide are externally infested by a number of parasitic insect and acarine species, collectively called ectoparasites. Ectoparasite, a word originating from the Greek words, ektos meaning outside and parasitos meaning parasite, refers to an organism that lives on the exterior of its host and to the detriment of that host. These ectoparasites include lice, mites, fleas, blowflies, blackflies, mosquitoes and ticks. They afflict humans and livestock alike, causing major socioeconomic losses and suffering of human life and livestock industry, predominantly as a result of transmission of a wide variety of pathogens (viruses, rickettsiae, spirochetes and bacteria, fungi, protozoa, filarial worms, and nematodes), some causing deadly dangerous zoonotic diseases [1-4]. In addition, they cause skin diseases, annoyance, uneasiness, itching, wounds (source of secondary infections), myiasis, hide/skin damage, reduction of meat, milk, blood, and wool production, and low income from the sales of farm animals and their products [5].

Of these blood-feeding ectoparasites, ticks are the most important arthropod disease vectors, surpassing all other haematophagous arthropods in number and variety of diseases they transmit to animals and humans [6]. By virtue of their protracted feeding period, ticks represent an extreme example of evasion of their host's haemostatic defenses and immune response, thus becoming better placed pathogen transmitters than any other arthropods known [7-12]. The lack of digestive enzymes in the tick gut favours the survival of ingested microorganisms and may explain why ticks transmit a greater variety of pathogens than any other haematophagous arthropods [13]. Notably, a wide range of tick-borne bacterial diseases (rickettsioses, ehrlichioses, Lyme disease, relapsing fever borrelioses, tularemia, and Q fever) and Omsk 


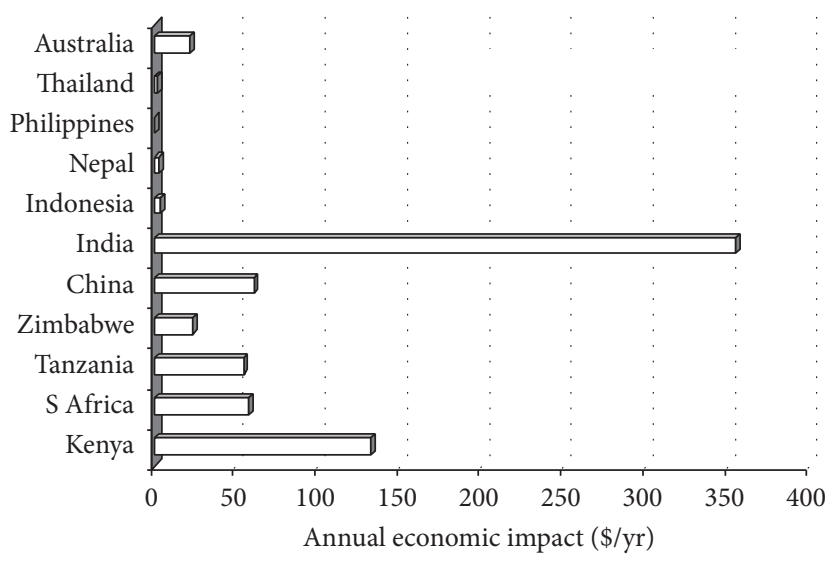

FIGURE 1: Annual economic impact of tick and tick-borne diseases (US\$m) as outlined by McLeod and Kristjanson [19].

hemorrhagic fever, louping-ill disease, tick-borne encephalitis, West Nile fever, and Crimean-Congo hemorrhagic fever are increasingly emerging diseases of human concern $[14,15]$.

Of all ectoparasites infesting livestock, ticks cause the greatest economic losses in livestock production systems at a global level $[6,13,16]$. However, in Africa (particularly in East Africa), tsetse flies, which infest only $40 \%$ of the continent [17], surpass ticks, which are found on the entire continent $(30 \mathrm{M} \mathrm{sq} \mathrm{km})$ in terms of socioeconomic losses incurred in livestock industry. Livestock ticks transmit a variety of aetiologic organisms (bacteria, protozoa, rickettsiae, and viruses) and the causative agents of a number of debilitating livestock diseases (theileriosis, heartwater, Nairobi sheep disease, streptothricosis, babesiosis/piroplasmosis, and anaplasmosis). These diseases, together with the abundance of the individual tick species, are widely distributed globally in tropical and subtropical regions [18]. The most economically important ixodid ticks infesting livestock in these regions belong to the genera: Amblyomma, Haemaphysalis, Rhipicephalus, Boophilus, Hyalomma, Dermacentor, and Ixodes.

The impact of ticks and tick-borne diseases (T\&TBDs) continue to be felt in rural Africa, Asia, and some parts of Americas with untold suffering and losses in livestock and livestock-dependent livelihoods [19]. Estimation of economic impacts of T\&TBDs is, however, confounded by lack of accurate estimates of disease prevalence, the heterogeneous nature of cattle production, and complexity associated with the estimation of direct and indirect disease-related production losses [19-22]. However, some annual costs due to T\&TBDs control and management in selected countries of Africa and Asia and also in Australia are shown in Figure 1. The economic losses were highest in India (\$US 355 million) and lowest in the Philippines. The annual economic costs of T\&TBDs per head are shown in Figure 2. They were lower in the Asia-Australia region than in Africa due to the fact that high intensity tick control and management methods are employed in African countries where a highly pathogenic tick-borne disease (East Coast fever caused by Theileria parva parva) is endemic [23], causing the highest cattle morbidity and mortality $[24,25]$.

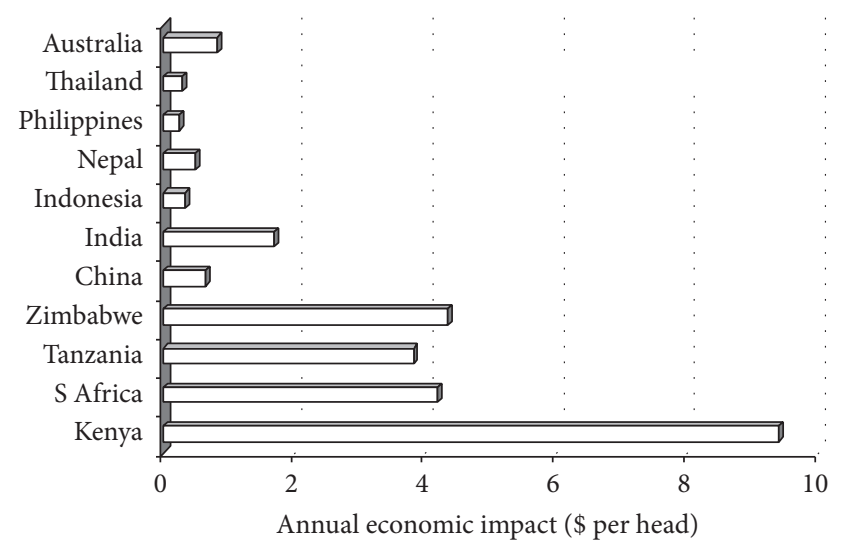

FIGURE 2: Annual economic impact of tick-borne diseases on a per head basis as outlined by McLeod and Kristjanson [19].

Despite progress in scientific research and development, T\&TBDs' control worldwide has continued to rely heavily on synthetic chemical acaricides. Overdependence on these acaricides diverted attention from exploring and developing sustainable alternative method(s) including traditional methods of tick control and management. Unfortunately, synthetic chemical acaricides have long become unsustainable to use in T\&TBDs' control and management interventions [23, 26-29]. Such compounds have suffered from a number of drawbacks, including acaricide resistance in ticks, their rocketing costs, pollution of the environment and food products (meat, blood, and milk) with toxic residues, deleterious effects on nontarget organisms, creation of an enzootically unstable disease situation, and the uncertainty of new acaricidal molecules being produced in the near future due to prohibitive costs of investment in research and development by the manufacturing firms [30]. Additionally, the efficacy of some acaricides/ectoparasiticides against some ectoparasites became questionable [31]. Societal and scientific concerns regarding exclusive dependency upon synthetic chemicals have emphasized the need for the development and introduction of alternatives to acaricides that are consistent with the principles of sustainable agriculture [32]. However, the alternative tick control interventions that exist, namely, use of ethnobotanicals including antitick pastures, biological mechanisms (parasitoids, predators, microbial agents, and nematodes), establishing endemic stability for tick diseases, manipulation of hybrid sterility between closely related tick species, hand deticking, habitat modification, pheromone- and host odor-mediated tick control methods, breeding tick resistant livestock strains, use of antitick vaccines, use of quarantine legislations, slaughtering infected animals, pasture spelling, use of fodder with high nutritional level to enable livestock withstand the stress caused by T\&TBDs, and use of tick models to help select cost-effective strategies, are selectively used with little success. Some are rarely used while others are still either under development or unknown to the end users (rural livestock farmers). People education and awareness campaign programmes and events like in the case of Lyme disease vector ticks in Europe and North America have never been 
effectively, efficiently, and extensively planned and conducted for the case of livestock ticks. The sustainability of tick control and management interventions are always marred with a variety of problems depending on formulated tick control and management strategies and policies, scientific opinions of stakeholders, and government legislation and political will of involved countries [33-35]. Shortcomings in certain tick control and management interventions such as partial control of Boophilus microplus by vaccination [29] and technical difficulties in execution of large-scale tick control and management interventions [36, 37] are among the obstacles that have continued to undermine successful T\&TBDs control operations even when using alternative methods available. Socioeconomic constraints, political strife, lack of trained personnel, and a poor infrastructure are major contributory factors to unsuccessful tick control and management interventions [22, 23, 33]. Incorrect administration of developed tick control tools and their continued failure to be efficient and effective are some of the obstacles reported during T\&TBDs control operations $[37,38]$. However, enforcement of appropriate legislation and good management of developed tick control interventions have, in the past, scored successes in some areas [22].

The failure of many developed tick control and management interventions has not been only due to the above problems but was also caused by the manner in which they are planned, developed, implemented, monitored, and evaluated [22]. For instance, many programmes are generated without taking into account the existing traditional livestock farming systems and conditions, production objectives, priorities, resource base, and technical-know-how of rural livestock farmers [39]. Many top-down tick control interventions rely solely on researchers' professional expertise to identify research problems and draw up research agendas and priorities without consulting and involving the end users' (rural livestock farmers) cultural values, social practices, and opinion $[40,41]$. Developing safe, economically affordable, user friendly, easily adaptable and accessible, environmentally friendly, and community-driven interventions well suited to local conditions and specific to rural livestock communities can be highly successful and would be desirable [21, 42]. Community-specific and locally available antitick plants [43, 44] and other none botanical antitick ethnopractices and agents $[43,45]$ are promising but neglected strategic alternatives in tick control and management programmes. Although work on these plants in 1980s and 1990s revealed a resource with great potentials (antitick plants with toxic, repellent, attractant, antifeedant, and growth regulating properties) [46], this strategy has remained neglected and unexploited [47]. Most important is the fact that these plants are holistic in action $[39,48]$ and, therefore, have many positive values to offer to rural livestock farmers [49]. Such a multipurpose intervention best fits the recent ascendancy of individual livestock owners as the main players in tick control programmes, particularly following the withdrawal of most African government agencies in mid-1980s [50, 51]. This paper reviews the potential role and contribution of ethnoknowledge on ectoparasite control with a special focus on ethnobotanical acaricides in integrated tick control and management programmes. The review constitutes a consolidated database of previously used or mentioned plants with antitick properties, including antitick knowledge reported in non-peer-reviewed publications. Only some of these plants so far have been experimentally evaluated and assessed for their acaricidal/ectoparasiticidal activity.

\section{An Overview of Sources of Information on Plants with Effects on Livestock Ticks}

This section describes and discusses a varied number of sources and methods used to access information on plants and plant products with effects on livestock ticks worldwide. The identification of sources of information of ethnobotany of veterinary importance, local veterinarians, paraveterinarians, and agricultural extension officers responsible for providing extension services to livestock farmers in Kenya were accessed and discussions held. Local livestock traders and dealers, as well as individual livestock farmers, contributed their knowledge of ethnoveterinary medicine based on their professional and economic activities. Local ethnopractitioners, including general traditional healers/herbalists, diviners, curse detectors, and specialized medicine men and women formed a particular special subset of knowledgeable people from whom information was accessed. Secondary data were key source of information for this particular study and provided a very important source of leading ethnobotanical information of veterinary importance. Sources of secondary data included the following: local veterinary offices, herbaria libraries, and websites/URLs and databases of various relevant research institutions and centres worldwide. All these groups were consulted because each was associated with a specific aspect of useful ethnobotanical knowledge relevant to the study.

\section{Ethnoknowledge of Ectoparasite Control and Management}

This is a culture-bound knowledge system found within ethnoveterinary medicine, which has evolved concurrently with human ethnomedicine [52-54]. Understanding ethnopractices involved in ectoparasite control and management is necessary in the verification processes so that any research effort is not wasted on chemical analysis of plants that are used for culturally specific reasons [55]. For example, a study conducted in Trinidad and Tobago on a wide range of ethnoveterinary plants [55], through cultural comparative analysis with reference to the existing literature and by a method of nonexperimental validation of herbal medicines/products, resulted in the following list of 13 cultural plants that were selected for use in integrated control and management of the cattle ticks, Boophilus microplus and Amblyomma cajennense (locally known as "Garrapat" and "Cayenne," resp.), the dog tick, R. sanguineus, and mites [56] (see Table 1).

Ancient communities particularly those that practiced pastoralism understood the concept of contagion and vectorborne disease of livestock involving ectoparasites [39]. They had control measures put in place to help avert economic 
TABLE 1: Plants used in the prevention, control, and management of ticks and mites of livestock in Trinidad and Tobago.

\begin{tabular}{lccc}
\hline Scientific name & Family & Plant part used & Known active and other components \\
\hline Azadirachta indica & Meliaceae & Leaves & Limonoids, azadirachtin, salannin, deacetyl-azadirachtin, and meliantriol \\
Cedrela odorata & Meliaceae & Leaves & - \\
Cordia curassavica & Boraginaceae & Leaves & Phenols and terpenoid quinones \\
Eclipta alba & Compositae & Plant tops & Polyacetylenes nicotine \\
Mammea americana & Guttiferae & Seeds & Mammein \\
Manilkara zapota & Sapotaceae & Seeds & HCN, sapotin, and saponin \\
Momordica charantia & Cucurbitaceae & Vine & - \\
Musa species & Musaceae & Stem juice & Caprylic acid and 5-hydroxy-tryptamine \\
Nicotiana tabacum & Solanaceae & Leaves & Nicotine \\
Petiveria alliacea & Phytolaccaceae & Leaves & - \\
Pouteria sapota & Sapotaceae & Seeds & - \\
Renealmia alpinia & Zingiberaceae & Leaves & - \\
Scoparia dulcis & Scrophulariaceae & Plant tops & \\
\hline
\end{tabular}

Note. Some of these plants were among the 43 plant species evaluated in Jamaica, whose crude ethanol extracts of the leaves for pesticidal effects on the engorged cattle tick, Boophilus microplus, were determined [57, 58]. Their acaricidal indices (AI) for the crude plant extracts ranged from 50 to 100 . Among the plants studied were Momordica charantia $(\mathrm{AI}=71)$, Azadirachta indica $(\mathrm{AI}=68)$, and Petiveria alliacea $(\mathrm{AI}=66)$.

losses incurred due to these parasites [39, 59-61]. Although most of the pertinent literature is anecdotal, several recent studies have shown that wild animals naturally select certain plant species and use them for management of ectoparasites infesting their respective places of residence [62]. Virtually all ancient stock raising societies had ways to control and manage livestock ectoparasites that plagued their animals. For instance, Nigerian Fulani correctly observed that Sammore (Trypanosomiasis) was spread by tsetse fly bites [63] and used a variety of traditional methods to control them [39]. The East African pastoralist communities knew long before the advent and introduction of western veterinary science that redwater scourge in cattle and heartwater bane in sheep were caused by the bite of grass ticks, which infested the grazing grounds [48]. Similar beliefs implicating ticks as vectors of deadly livestock diseases were held by Somali [61], Dinka [64], Fulani [60], and South African early settlers [39]. Other ectoparasites well known to ancient stock raisers as sources of livestock diseases include the following: biting flies, fleas, lice, and mites (causative agents of livestock mange/scabies) [48]. Control and management of these livestock ectoparasites have been summarized in Table 2. Within the phylum Arthropoda, one ethnoremedy technique or practice could or can be used for controlling and managing more than one ectoparasite [48]. For instance, Nicotiana tabacum decoction/suspension was used by the Gikuyu women in Kenya to control ticks, by the Nigerians to control biting flies, by the Bulgarian nomads and the Andeans to control mites, mange, and scabies, and by the Samburu in Kenya to control leeches (Table 2). This shows the holistic nature of ethnobotanical remedies (natural bioactive compounds from plants), the much needed technology [65] suitable for deployment in integrated pest management by resource-poor livestock farmers [22].

\section{State of Knowledge on Ethnobotanicals That Affect Livestock Ticks}

The world is endowed with a vast diversity of plants ranging from microbial organisms, terrestrial plants, to marine flora. Throughout the evolutionary history, these plants have been an important resource for human and animal community. Besides being a source of food, several of these plants have been investigated for medicinal and pesticidal activities, while others are being explored for plant and arthropod growth regulators, allelochemicals, arthropod antifeedant, repellent, and toxicity. Some of these have potential for serving vital prototypes for structure optimization chemical technology [92].

Today, there is a growing appreciation of the value of ethnobotanical veterinary knowledge (EVK) among western trained professionals and periurban communities around the world [18, 48, 67, 93-100]. Because of great interest in and acceptance of EVK as alternative for disease control, ethnoveterinary research and development (ER\&D) of which antitick ethnoknowledge is an integral part, has become a fertile area of technology development [101]. This knowledge has proved valuable not only to those who depend on it in their daily lives (mainly pastoralists) but also to modern industries and agriculture as well [48, 97, 102]. Many widely used products, such as plant-derived pharmaceuticals, acaricides, nutraceuticals, functional foods, hormones, pesticides, herbicides, insecticides, aromatics, and cosmetics, originate from traditional knowledge as their source [102-104]. EVK provides hope for economically impoverished local communities whose livelihood is livestock-dependent $[48,94$, 95, 99, 105, 106]. Applications and studies of EVK have put more emphasis on the control and management of livestock ectoparasites (Table 2). The current review focuses on 
TABLE 2: Traditional prevention, control, and management of livestock ectoparasites by native and local communities.

\begin{tabular}{ll}
\hline $\begin{array}{l}\text { Target livestock } \\
\text { ectoparasite(s) }\end{array}$ & A description of traditional remedy \\
\hline Small red flies & $\begin{array}{l}\text { (i) Setting smudge fires in the sheds } \\
\text { (ii) Rubbing kerosene and other substances on the animals }\end{array}$
\end{tabular}

(ii) Rubbing kerosene and other substances on the animals

(i) Feeding salty plants to animals so that the ticks can fall off

(ii) Every morning, picking off and burning any ticks they find on their animals

(iii) Placing thorn bushes on infested places so that camels should not roll on them

(i) Pounding 5 leaves of Aloe broomii and mixing with $300 \mathrm{ml}$ of paraffin oil and 2 handfuls of kitchen ash to make a paste for smearing on the infested parts of the animal

(ii) Use of hagar, Commiphora erythraea, or damaji, C. incisa, by Gabbra and Somali in Kenya

(iii) Smearing leaf paste of eteteleit, Acalypha fruticosa, by the Turkana in Kenya

(iv) Bathing animals with salt solution ( $100 \mathrm{~g}$ of salt dissolved in 1 litre of water)

(v) Rubbing old engine oil on infested areas of the animal's body

(vi) Allowing animals to wallow in shallow, muddy pools

(vii) Using animal quarantine techniques to keep infected stock away from noninfected one

(viii) Removal of weeds and bushes from livestock housing

Tick infestation in livestock populations

(ix) Predation of ticks by birds-keeping chickens in and around the animal housing

(x) Raising neem, Azadirachta indica, or other tick-repellent plants near animal housing

Use of tobacco, Nicotiana tabacum, by the Gikuyu in Kenya

(i) Avoiding infested pastures, fodder, shade trees, and cool places which favour ticks' survival

(ii) Burning of livestock pastures and tick-infested manure in the sheds

Drenching animals with a mixture of salt and six ground fruits by the Twareg

Handpicking of ticks during milking by Fulani women and children in Burkina Faso

Use of toasted maychia leaves to drive out ear ticks in herd animals in Peruvian Andes

A herbal preparation pestban in control of ectoparasites in household pets and domesticated animals in India

Acaricidal activity of the combination of plant crude extracts to tropical cattle ticks (Boophilus microplus) in India

A herbal ectoparasiticide AV/EPP/14 against lice and tick infestation on buffalo and cattle in India

Lighting smudge fires beside resting buffalo, cattle, Amerindian horses, Siberian reindeer, and

\begin{tabular}{ll}
\hline Livestock insects & $\begin{array}{l}\text { Lighting smudge fires beside resting buffalo, cattle, Amerindian horses, Siberian reindeer, and } \\
\text { Andean guinea pigs }\end{array}$ \\
\hline & Andeans burnt old tires in corrals
\end{tabular}

In Andean region, corrals were sprinkled with lime, kerosene, or creosote on affected animals

Livestock pests Seasonal burning of rangelands used for grazing in Andes and Africa

A herbal preparation pestban in control of ectoparasites in household pets and domesticated animals \begin{tabular}{ll}
\hline Parasitic Insects & Fumigation of animal quarters and camps with herbs by Nigerian Pastoralists \\
\hline Washing cattle with an infusion of Sesbania aculeata, ointments, dust, and tobacco by Nigerian
\end{tabular} $[63,71]$ pastoralists

Tsetse flies

(i) Bathing animals' body with emulsion made from roots of Cissus purpurea

(ii) Bathing animals' body with emulsion made from leaves of Sesbania sesban in Kenya

(iii) Smearing the oil of neem, Azadirachta indica, seed kernels on animals' bodies

(iv) Smearing the latex of Euphorbia balsamifera on the bodies of affected animals

(i) Nigerian horses bathed with fly-repellent liquids

(ii) Yoruba employed soap mixed with graded roots of the violet tree

(iii) Northern Nigerians applied tobacco-based ointment

Livestock biting flies

Venezuelan fly repellent was a wash of squash-leaf juice

(i) Washing animals with a suspension of fresh root of anthata of Gabbra in Kenya

(ii) Smoke from burning cow dung drove the flies away

(iii) Position livestock sheds to allow wind to blow flies away and avoid flies-infested areas

A herbal ectoparasiticide AV/EPP/14 against lice and tick infestation on buffalo and cattle in India

(i) Sweep livestock sheds with brooms of Tagetes minuta (Mexican marigold) or desert rose,

Livestock fleas and lice

Adenium obesum, or burn T. minuta leaves in sheds and wash cattle with A. obesum

(ii) Sprinkling Magadi soda powder in sheds or wash animals with suspension of A. obesum

(iii) Wash animals with suspension of Aloe spp. (A. secundiflora, A. kedongensis, and A. lateritia) 
TABLe 2: Continued.

\begin{tabular}{|c|c|c|}
\hline $\begin{array}{l}\text { Target livestock } \\
\text { ectoparasite(s) }\end{array}$ & A description of traditional remedy & References \\
\hline Livestock lice per se & $\begin{array}{l}\text { (i) Wash animals with suspension of Aloe spp. and sisal, Agave sisalana } \\
\text { (ii) Smearing cattle with mixtures of fruits of adekelait and akej etom of Turkana in Kenya } \\
\text { (iii) Wash animals with suspension of garlic, Allium sativum } \\
\text { (iv) Use of eucalyptus, blue gum, Eucalyptus spp. } \\
\text { (vi) Rubbing camel's urine on the infested animals' skins } \\
\text { (vii) Smearing a mixture of camel's urine and salty soil on animal's skin } \\
\text { (viii) Smearing cow dung on the infested body areas of the animals } \\
\text { (ix) Smearing goats', donkeys', sheep's, and camel bones' fat over the animals' bodies } \\
\text { (x) Washing affected animals with natural salty water } \\
\text { (xi) Rubbing a paste of clay (dhoobo in Somali) on the affected animals } \\
\text { (xii) Shaving camels' hair and rubbing skin with a mixture of camel's urine and salty soil } \\
\text { (xiii) A herbal preparation pestban in control of ectoparasites in household pets and domesticated } \\
\text { animals } \\
\text { (xiv) A herbal ectoparasiticide AV/EPP/14 against lice and tick infestation on buffalo and cattle }\end{array}$ & \\
\hline Nasal bots & $\begin{array}{l}\text { (i) Putting in nostril a suspension of root of abach by the Turkana of Kenya } \\
\text { (ii) Keeping animals away from thickets in the rainy season } \\
\text { (iii) Giving animals drinking water at salty sources to enable them expel the larvae } \\
\text { (iv) Putting in nostril a suspension of root of entulelei (Solanum incanum) or olgrigiri (Acacia } \\
\text { brevispica) by the Maasai of Kenya } \\
\text { (v) Putting in nostril juice from ripe fruits of sodom apple, S. incanum, by Kamba people } \\
\text { (vi) Putting in nostril a teaspoonful of root suspension of Ingalayioi (Cucumis sp.) by the Samburu } \\
\text { of Kenya } \\
\text { (vii) Putting sheep milk into nostrils of affected animals to make them sneeze out maggots } \\
\text { (viii) Passing in nostril smoke of the bark of Ingeriyioi or Imasei (Tarenna graveolens) by the } \\
\text { Samburu of Kenya }\end{array}$ & \\
\hline Leeches & $\begin{array}{l}\text { (i) Use of tobacco, Nicotiana tabacum, and Saali le tim suspension by Samburu in Kenya } \\
\text { (ii) Avoiding leech-infested areas and physically removing attached leeches from animals }\end{array}$ & {$[67]$} \\
\hline Swine ectoparasites & Banana leaves and an extract of garlic in Central Brazil & [79] \\
\hline Chicken lice & A wash of vinegar and lemon juice by Andean people & [39] \\
\hline Skin sores of cattle & Dust with the powdered dung of ostriches and hyenas by the Neur & [59] \\
\hline \multirow[t]{2}{*}{ Lice and mites } & $\begin{array}{l}\text { A herbal preparation pestban in control of ectoparasites in household pets and domesticated } \\
\text { animals }\end{array}$ & {$[70,71]$} \\
\hline & Andean stockowners used barbasco & {$[80]$} \\
\hline \multirow{9}{*}{$\begin{array}{l}\text { Mange/scabies caused by } \\
\text { ectoparasitic mites }\end{array}$} & Root of Rumex patientia L. & {$[81]$} \\
\hline & Latex from Euphorbia somaliensis or camel urine & {$[82]$} \\
\hline & An infusion of Iphiona rotundifolia plant & {$[61]$} \\
\hline & Rubbing rhubarb and caustics into the mange lesions in China & {$[83]$} \\
\hline & Rubbing a decoction of tobacco leaves into the mange lesions by Bulgarian nomads & \\
\hline & Topical application of wild tobacco leaves and black soap by the Andeans & [39] \\
\hline & $\begin{array}{l}\text { Andean muna (Minthostachys andina) and tarwi plant (Lupinus mutabilis) provide treatment for } \\
\text { mange }\end{array}$ & \\
\hline & $\begin{array}{l}\text { In France, milk, vinegar, olive oil, lard, ashes, soot, sulphur, turpentine, crankcase oil, and mineral } \\
\text { waters were administered as pomades, plasters, lotions, drenches, or feeds. }\end{array}$ & {$[39,84]$} \\
\hline & $\begin{array}{l}\text { (i) Washing animals with a suspension of (Oldarakwa) pencil cedar, Juniperus procera } \\
\text { (ii) Drenching and smearing animals with a suspension of ash made from branches of Ngadapala } \\
\text { (Dobera glabra) by Kenyan pastoralists (Turkana) } \\
\text { (iii) Keeping animals' pens and surroundings clean and dry } \\
\text { (iv) Using animal quarantine techniques to keep infected stock away from noninfected one } \\
\text { (v) Smearing motor oil and or sesame oil on the affected areas of the animals } \\
\text { (vi) Turkana people use a suspension made from stems of eligoi to drench and wash animals } \\
\text { (vii) Use of Iparaa, Euphorbia sp., by Samburu of Kenya } \\
\text { (viii) Powdered charcoal of esekon (toothbrush tree), Salvadora persica mixed with } 1 \text { litre of ghee } \\
\text { to make a paste for topical application by the Turkana }\end{array}$ & {$[67]$} \\
\hline $\begin{array}{l}\text { Alpaca mange (caused } \\
\text { by mites) }\end{array}$ & $\begin{array}{l}\text { Use of pig fat, rancid camelid grease, boiling-hot lard, rancid urine, sulphur, stove ash, soot from } \\
\text { earthen cookpots, masticated coca leaf, old motor oil, and battery acid }\end{array}$ & {$[81,85-89]$} \\
\hline \multirow{2}{*}{ Ruminant ectoparasites } & Water of tarwi plant, L. mutabilis, combined with ash of burnt cattle manure & {$[69,90]$} \\
\hline & Compounds of tarwi plant, L. mutabilis, and other botanicals by Andean smallholders & {$[86,91]$} \\
\hline
\end{tabular}


traditional control and management of livestock ticks, with a special focus on ethnobotanical substances that affect and modify tick behaviours.

Antitick ethnobotanical knowledge has its origin too rooted in trial and error traditional practices of ancient people. This was an early attempt to free livestock from ticks and other related arthropod pests. Before the advent of modern acaricides, a number of them being defunct now, ancient communities had developed a number of ways of controlling and managing arthropod pests of livestock, ticks inclusive (Table 2). Today, these ancient practices continue to yield interesting and potentially useful research leading to scientific discovery of much needed acaricides. For instance, the demonstration of repellent properties of molasses grass, Melinis minutiflora Beauv. (Poaceae) against Margaropus annulatus australis in South America by Menendenz (1924) [107], was much guided by ethnoknowledge of indigenous communities. Following this initial understanding, ten years later, De Jesus (cited by Thompson and coworkers [108]) was able to demonstrate too that $M$. minutiflora had deleterious effects on ticks, Boophilus australis. After 43 years of De Jesus observation, Thompson and coworkers [108] too observed that molasses grass together with gamba grass, Andropogon gayanus Kunth (Poaceae), showed tick-repellent properties in pastures in Colombia. In Africa, there was not any such report on antitick plants until the early 1990s when Dipeolu and coworkers (1992) [109] reported the acaricidal potential of an African spider flower, Gynandropsis gynandra (L.) Briq. (Capparaceae). This therefore implies that, up to date, meaningful research and development on antitick plants are still lacking. However, based on the compilation of literature on the said botanicals (Table 3 ), there is much evidence that some plants contain compounds that affect and modify tick behaviour (referring to botanicals with ability to kill, repel, immobilize, and affect tick fecundity and growth). For instance, plants of the genus Stylosanthes, apart from being a tropical forage legume, have shown great potentials for immobilizing and killing tick larvae [110-115]. Pastures with M. minutiflora have been shown to affect ticks by reducing their ability to live for longer $[107,108]$, thus an implication for the presence of some compounds that may induce tick mortality. In East Africa, G. gynandra has been shown to have antitick properties in pasture lands [44, 109]. In Kenya, a number of plants have been shown to affect and modify tick behaviours, particularly with repellency potentials. For instance, Commiphora erythraea and C. myrrh [116]; gum of C. holtziana [117]; Cleome monophylla [118]; Ocimum suave [119]; and G. gynandra [120] have been demonstrated to contain essential oils which have repellent components against Rhipicephalus appendiculatus. Various tribes in Kenya have traditionally used different plant-derived materials to control ticks. For instance, Gikuyu people (women) have used leaves of tobacco, Nicotiana tabacum [121]; Somalis have used gum resins and myrrh of Commiphora spp.; Luos in Nyanza have used leaves of Aloe spp.; and the Turkana people use leaves of Acalypha fruticosa to control and manage livestock ticks [67]. In Kenya, some tribes grow neem (Azadirachta indica) and or other plants they consider to have repellence property such as Euphorbia balsamifera, Sesbania sesban, and Cissus purpurea near animal housing for the purpose of repelling ticks [67]. Although a number of these plants have been documented in some local communities and some scientifically evaluated, still rural livestock farmers, extension workers, and other relevant stakeholders cannot put them on beneficial and wider utilization due to lack of information on their formulation, standardization, optimal concentration, and application regimes. This has been partly attributed to lack of knowledge on the identity and description of plants' active substances, which affect and modify tick behaviours.

This review provides a list of plants (Table 3) with leading information on how they affect and modify the behaviours of various livestock tick species under different geographical and environmental conditions. In addition, the review gives a basis for scientific research on the development of natural products for tick control and management and tick-borne diseases.

\section{Plant Species with Prospects for Tick Control and Management in Africa: Opportunities and Threats}

Table 3 presents a list of enumerated 209 plant species with their correct botanical and common names arranged in the first column, followed by family names in the second column, plant part(s) used in the third column, application form and action in the fourth column, location in the in the fifth column, and references made in the last column. Practically, all these plants have been "discovered" through information derived about their use in traditional medicine sense. The plant species showed a wide range of bioactive properties on different livestock tick species with $40 \%$ of 210 reported research on ethnobotanical acaricides being conducted in Africa, which is the most affected continent with tick infestation and tick-borne diseases, and henceforth, the associated socioeconomic losses [23]. This provides for the feasibility of controlling livestock ticks in Africa with plants and their products as components of an integrated tick control and management programme. This feasibility is justified by numerous scientific and socioanthropological reports of surveys and laboratory studies on African plants with effects on livestock ticks $[104,126,127,129,149,151,165,166,199$, 204-210]. A number of plants that have been conventionally examined for acaricidal properties include Melinis minutiflora [119, 211], Commiphora erythraea and C. myrrh [116], Ocimum suave [179], Margaritaria discoidea [174], Tephrosia vogelii [199], Azadirachta indica [46, 141, 142, 212], Nicotiana tabacum [43], Gynandropsis gynandra [44, 109, 120], Euphorbia candelabrum [140], and Ageratum houstonianum [126]. Other many African plant species with potential for use in tick control and management programmes have been documented and recorded during the many ethnoveterinary survey studies conducted in local African communities [47, $67,104,117,127,151,153,165,166,198,199,208]$. These surveys play a key role in providing a common ground for conventionally trained researchers and ethnopractitioners (rural resource-poor livestock farmers) to meet and interact 


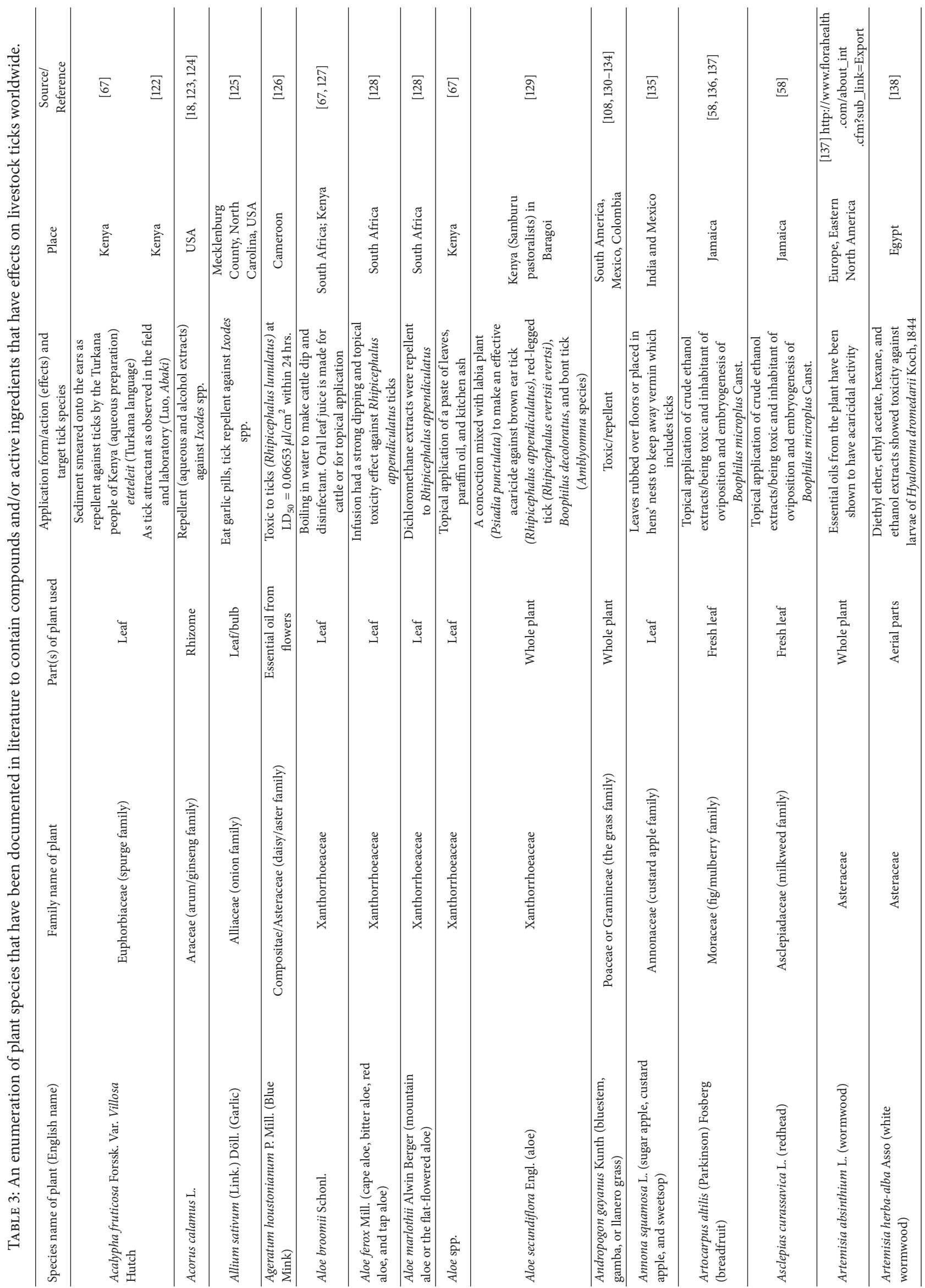




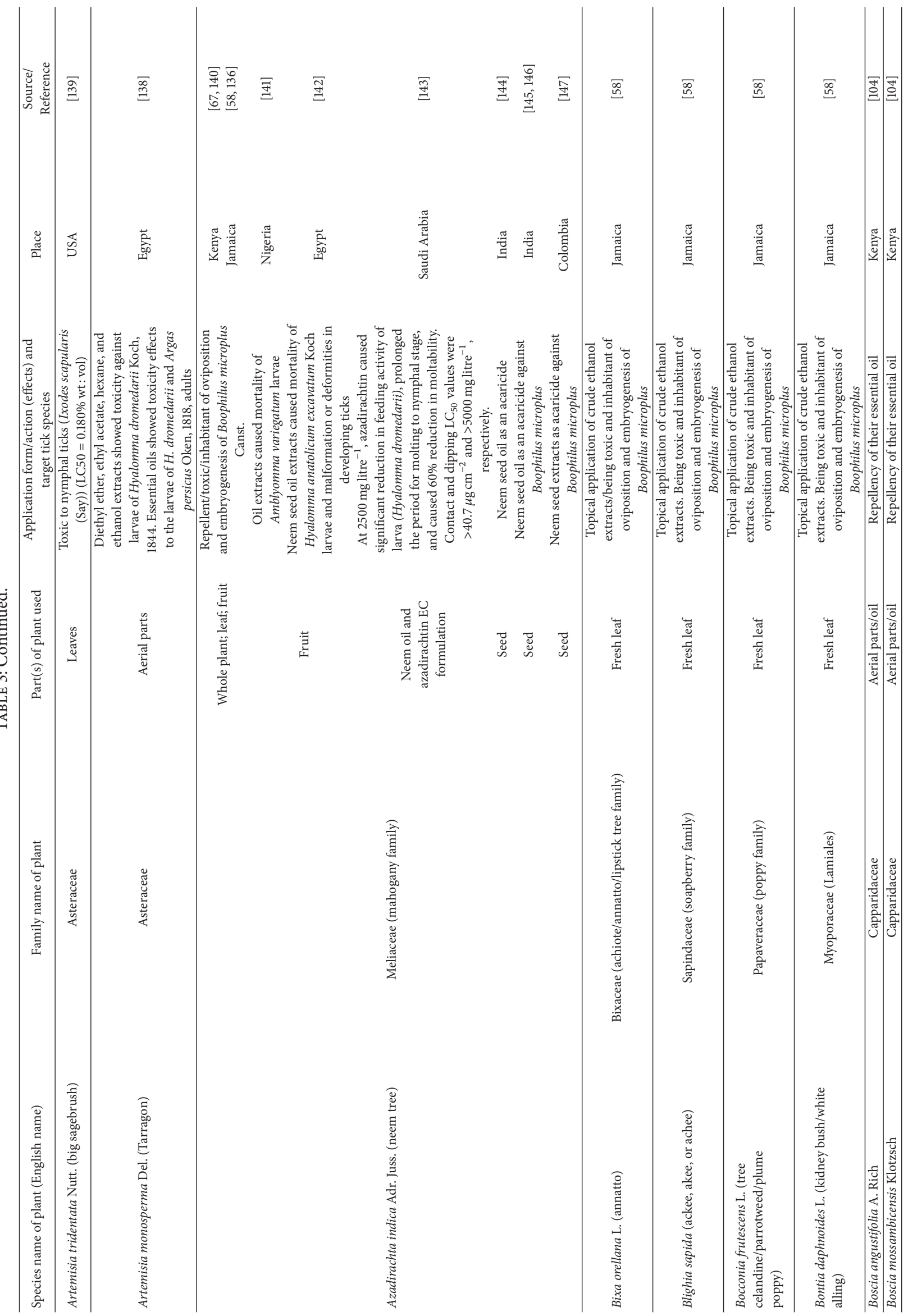




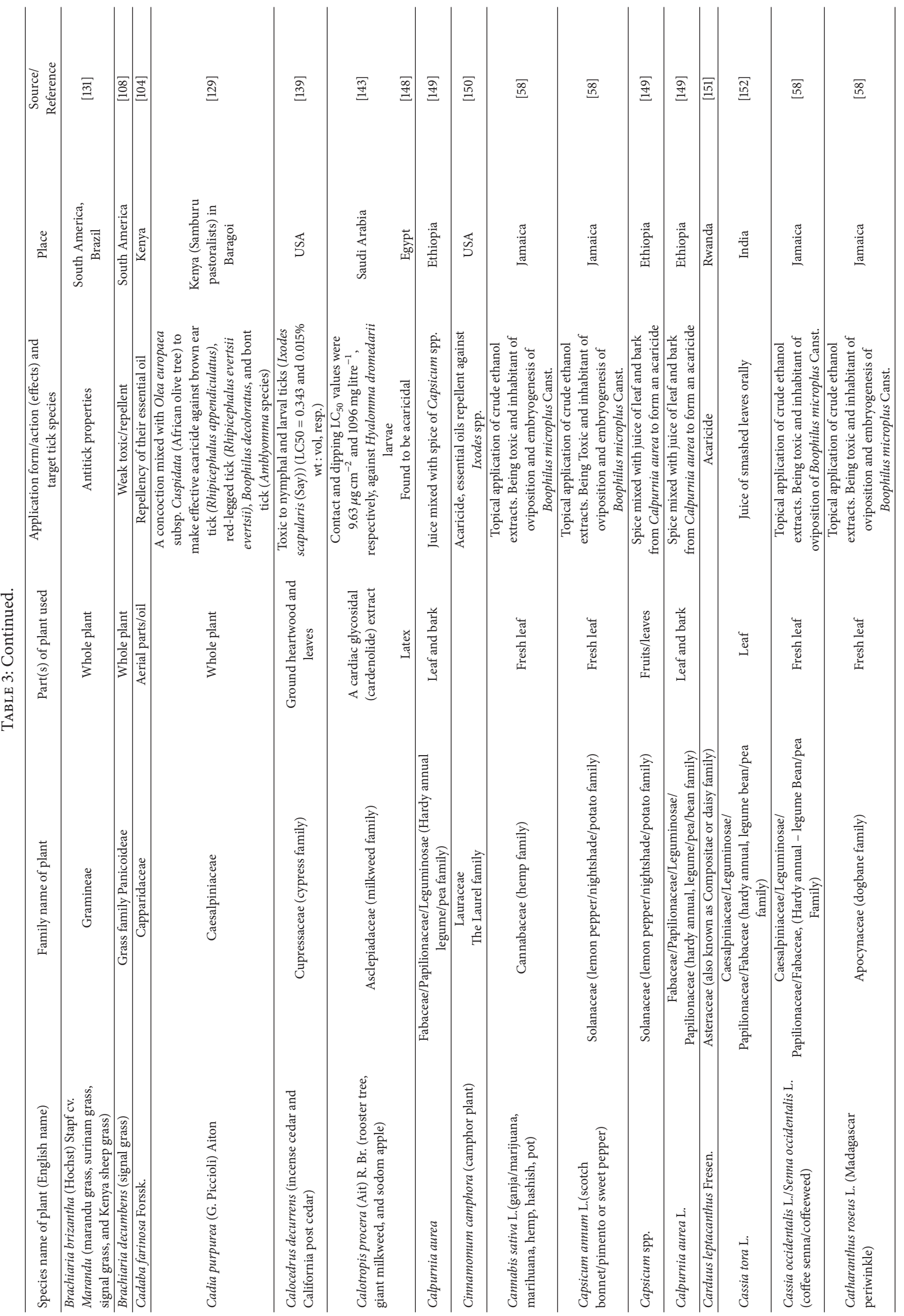




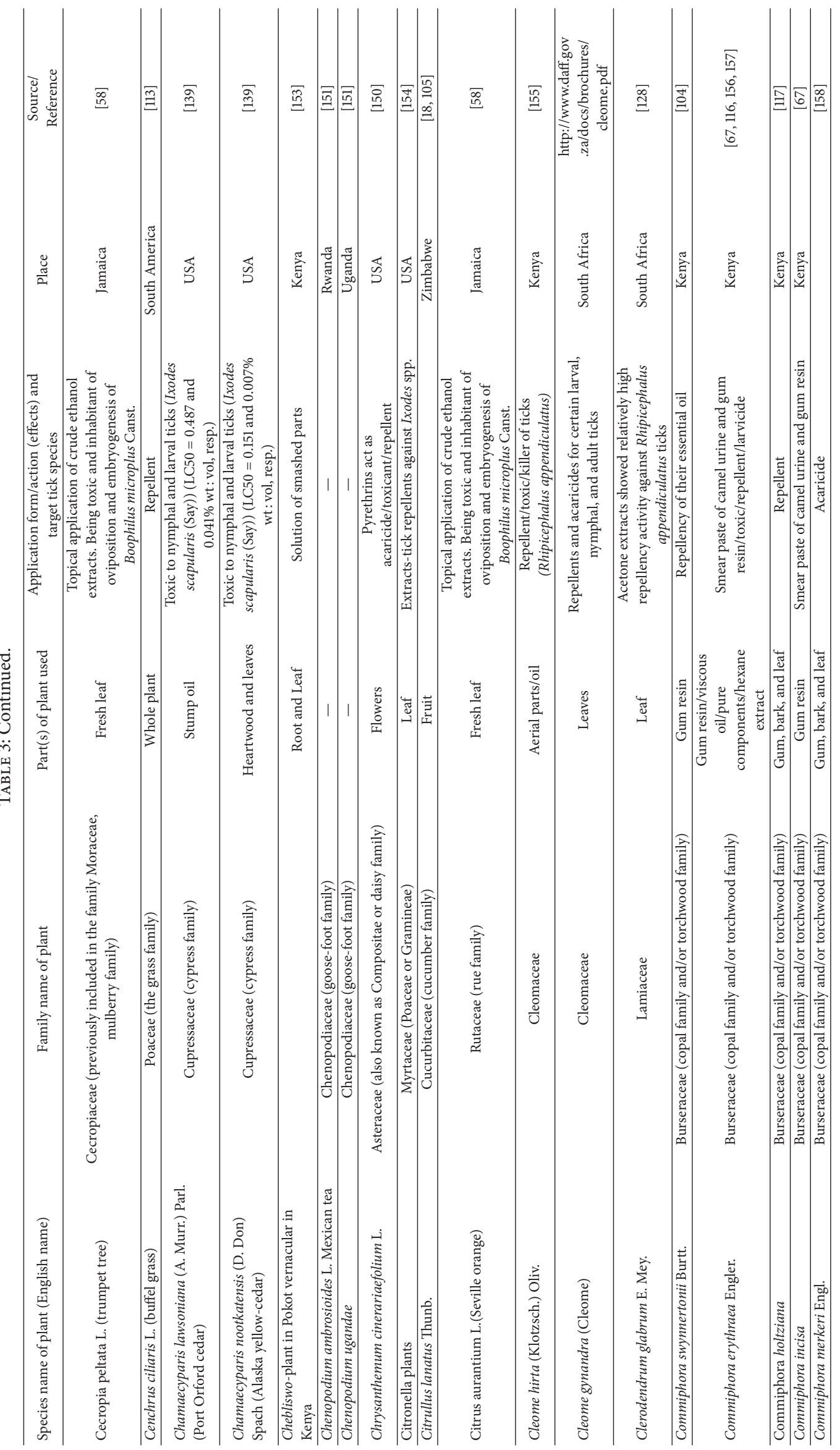




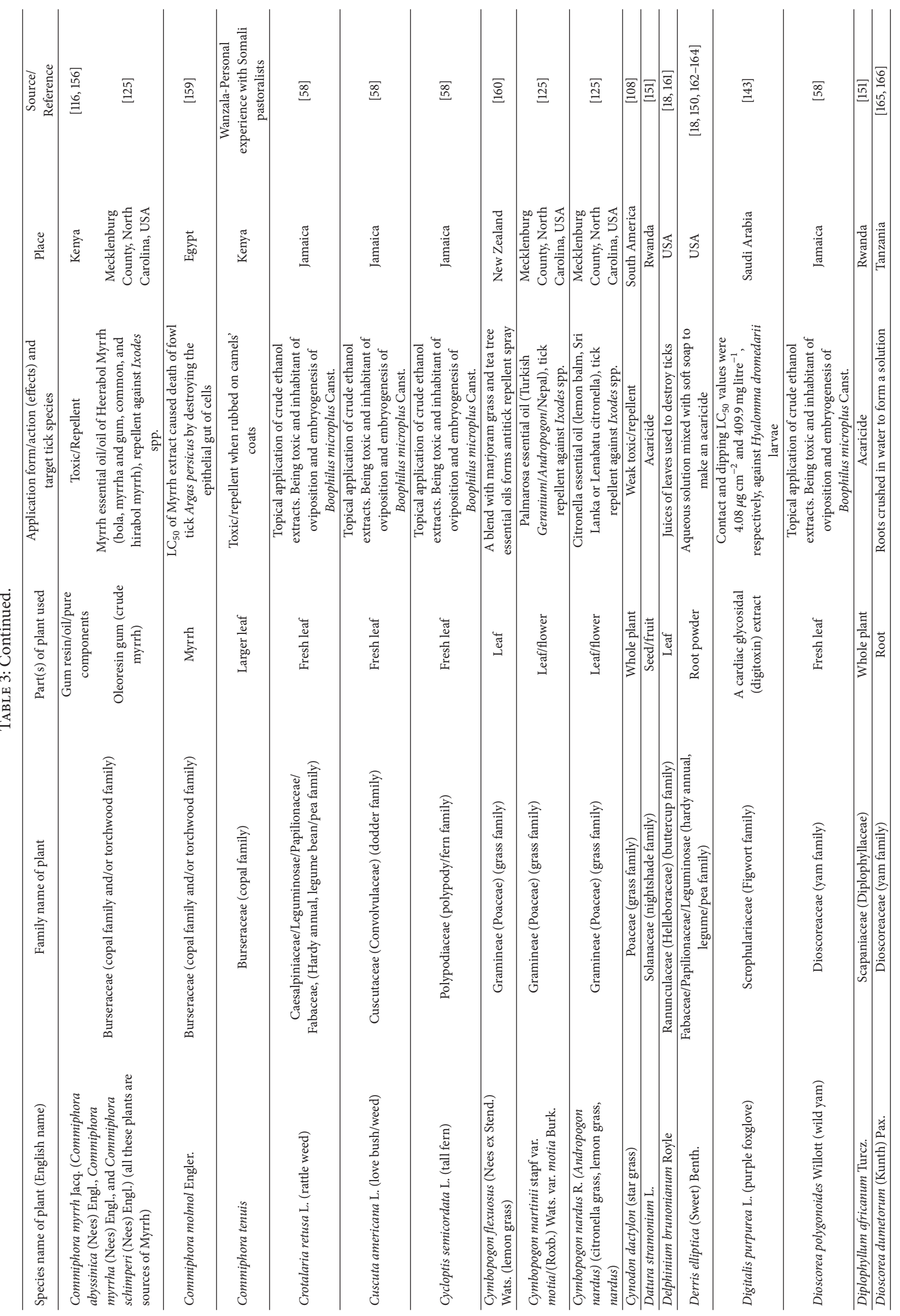




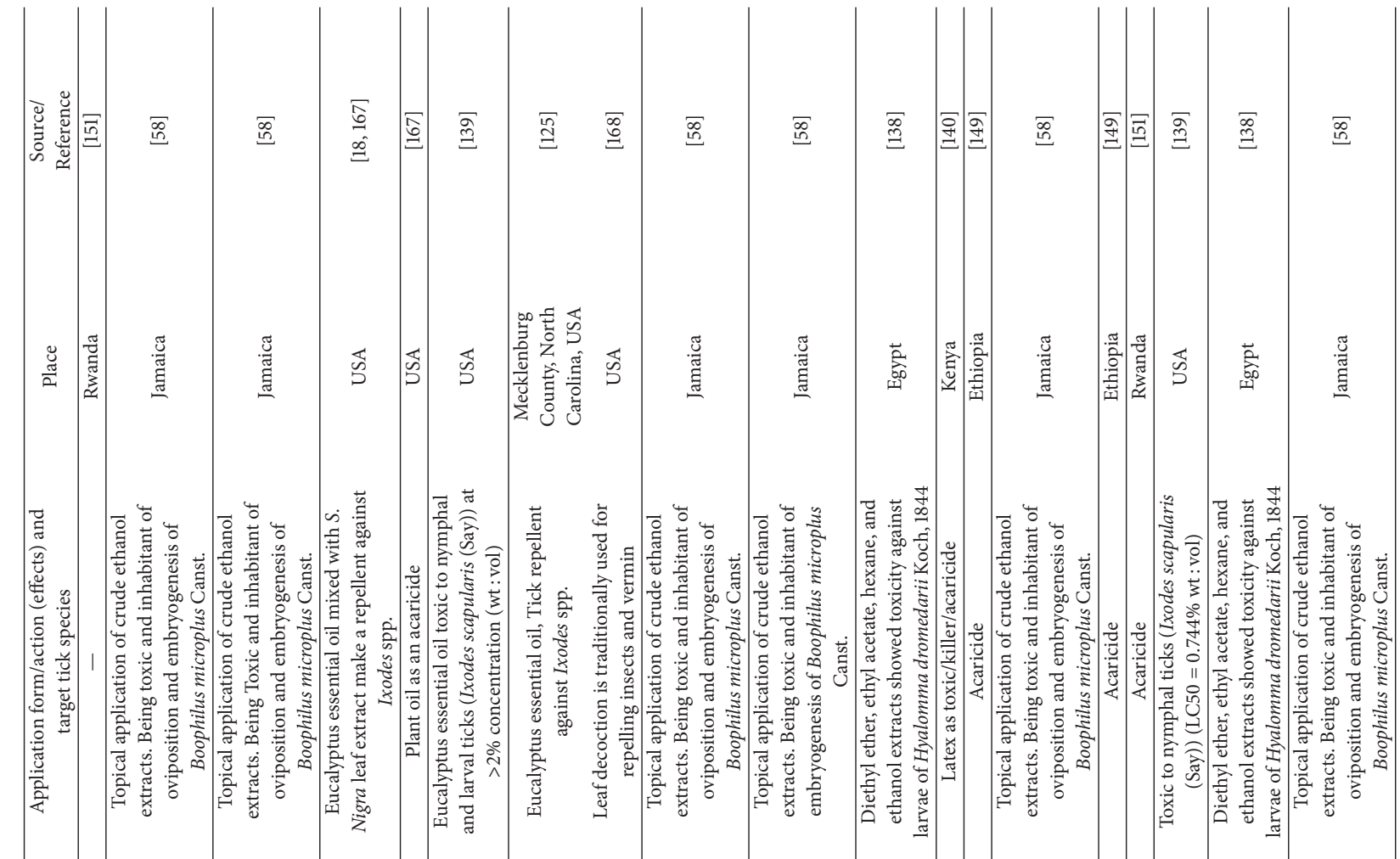

离

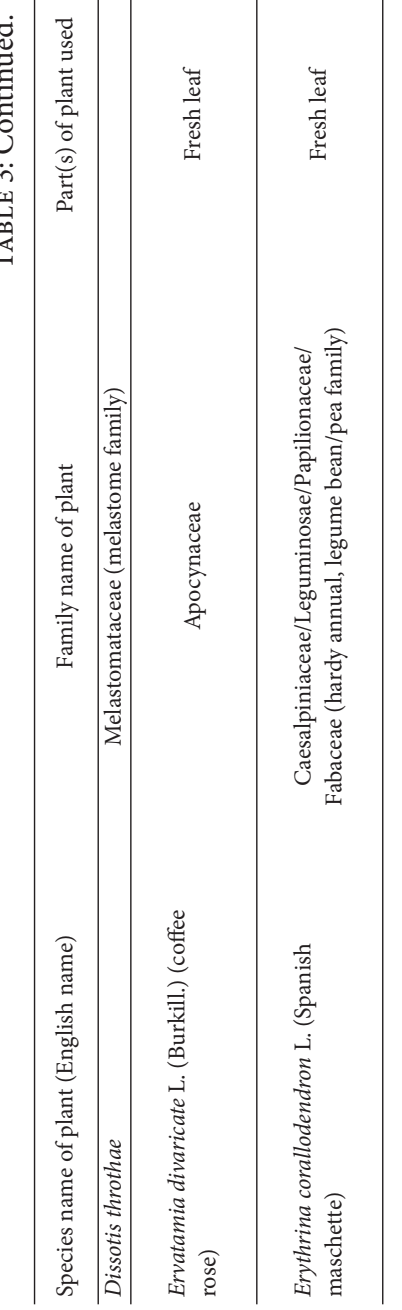

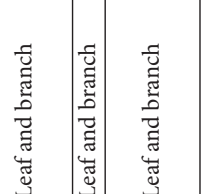

एँ

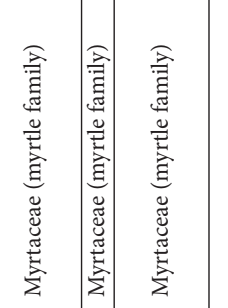

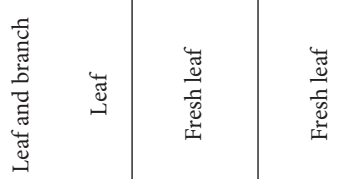

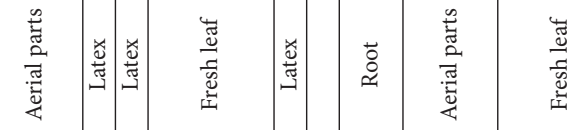

逽

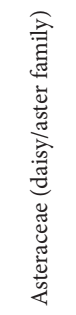

른
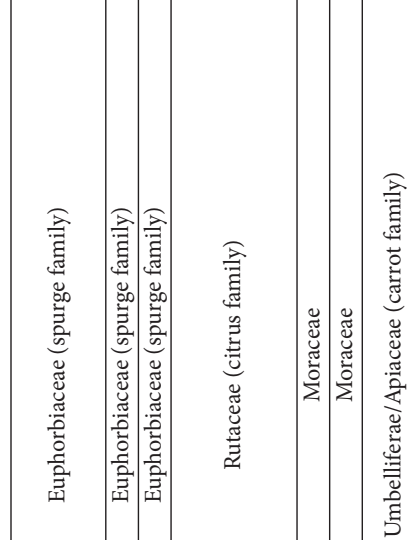

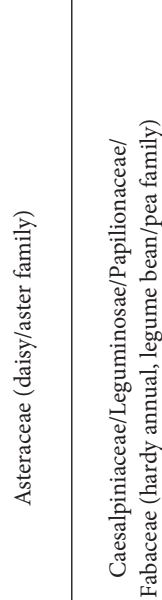

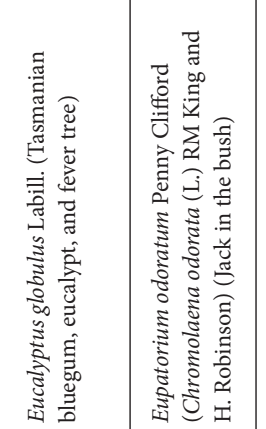

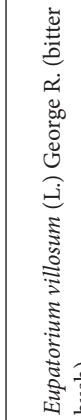

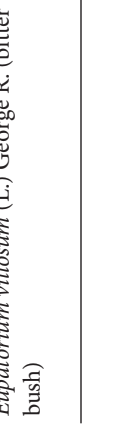

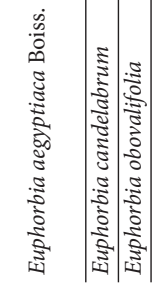

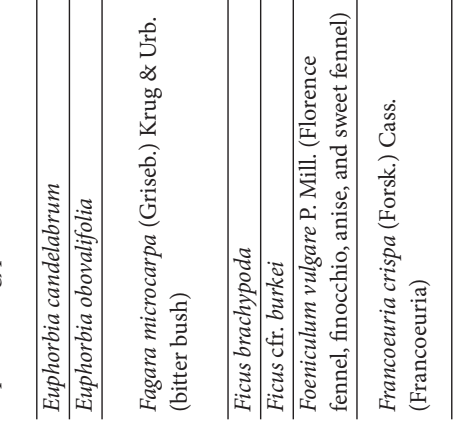

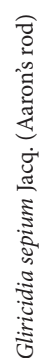




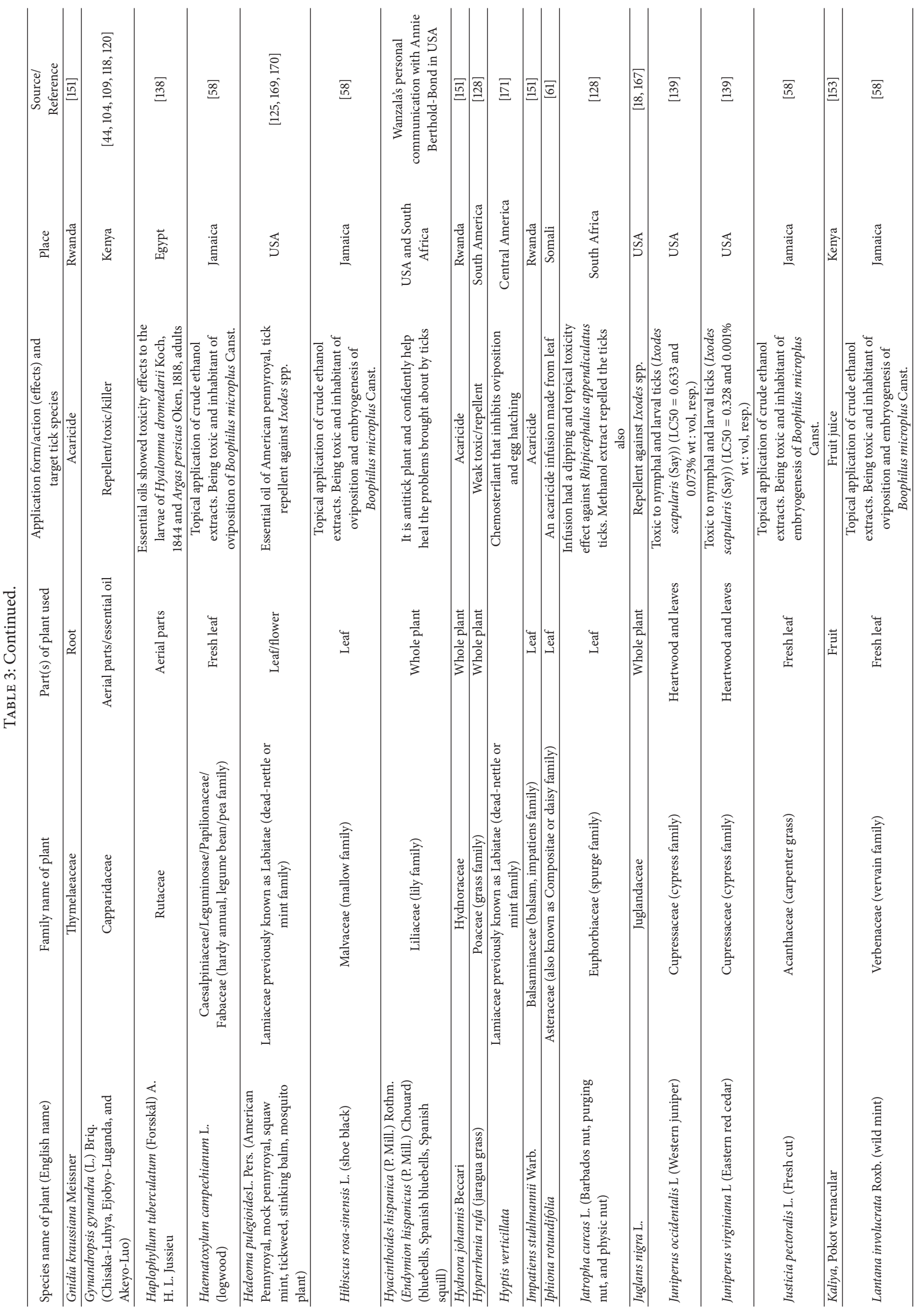




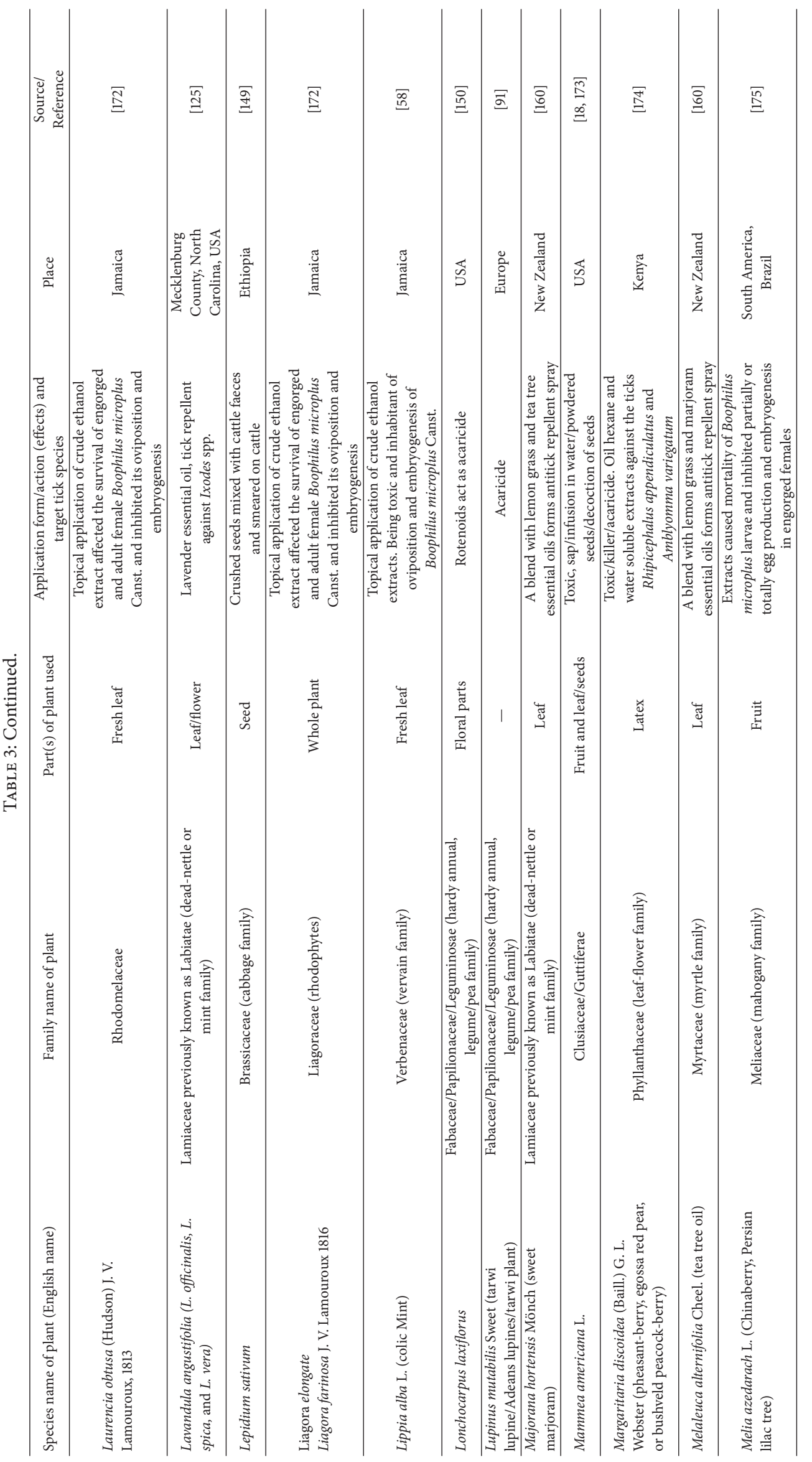




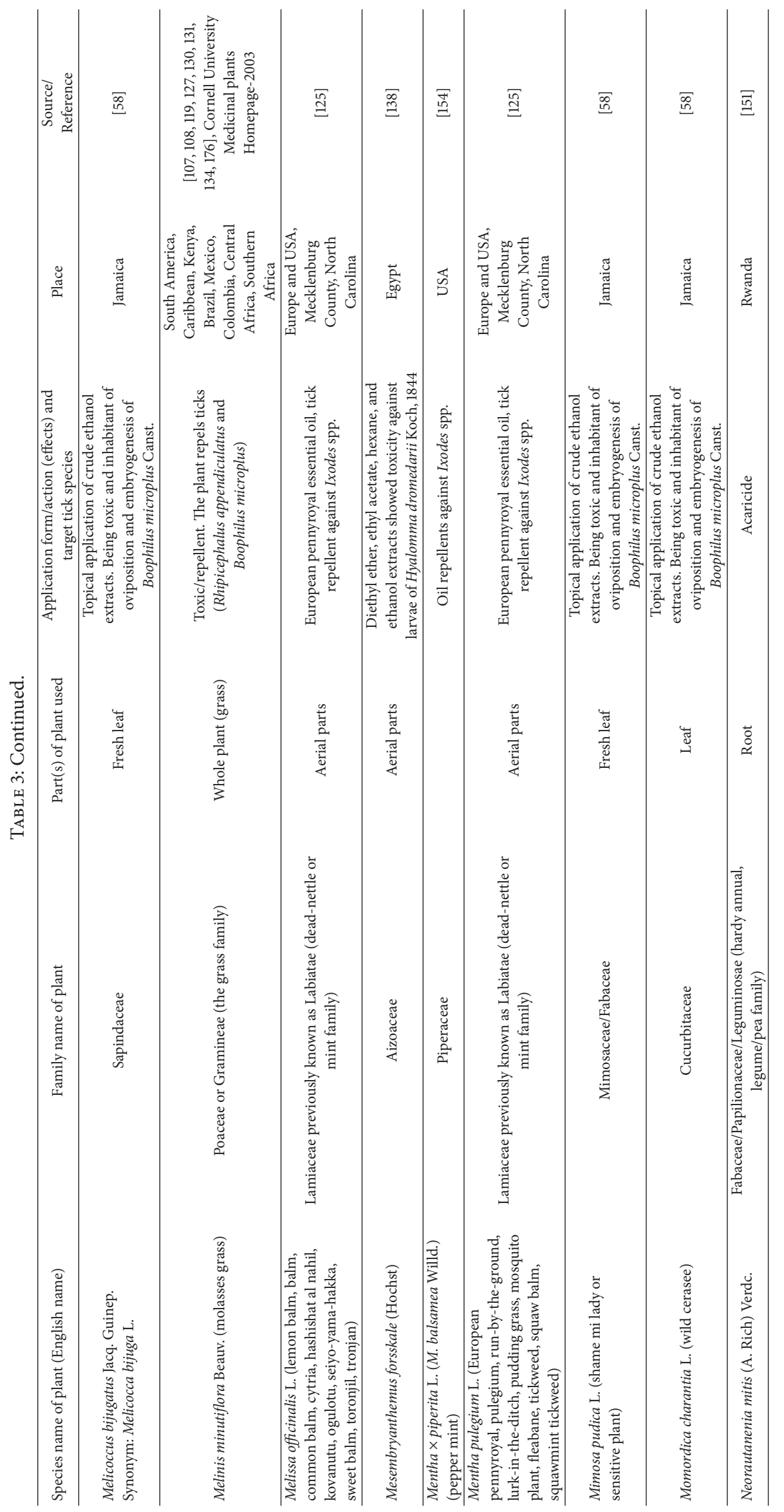




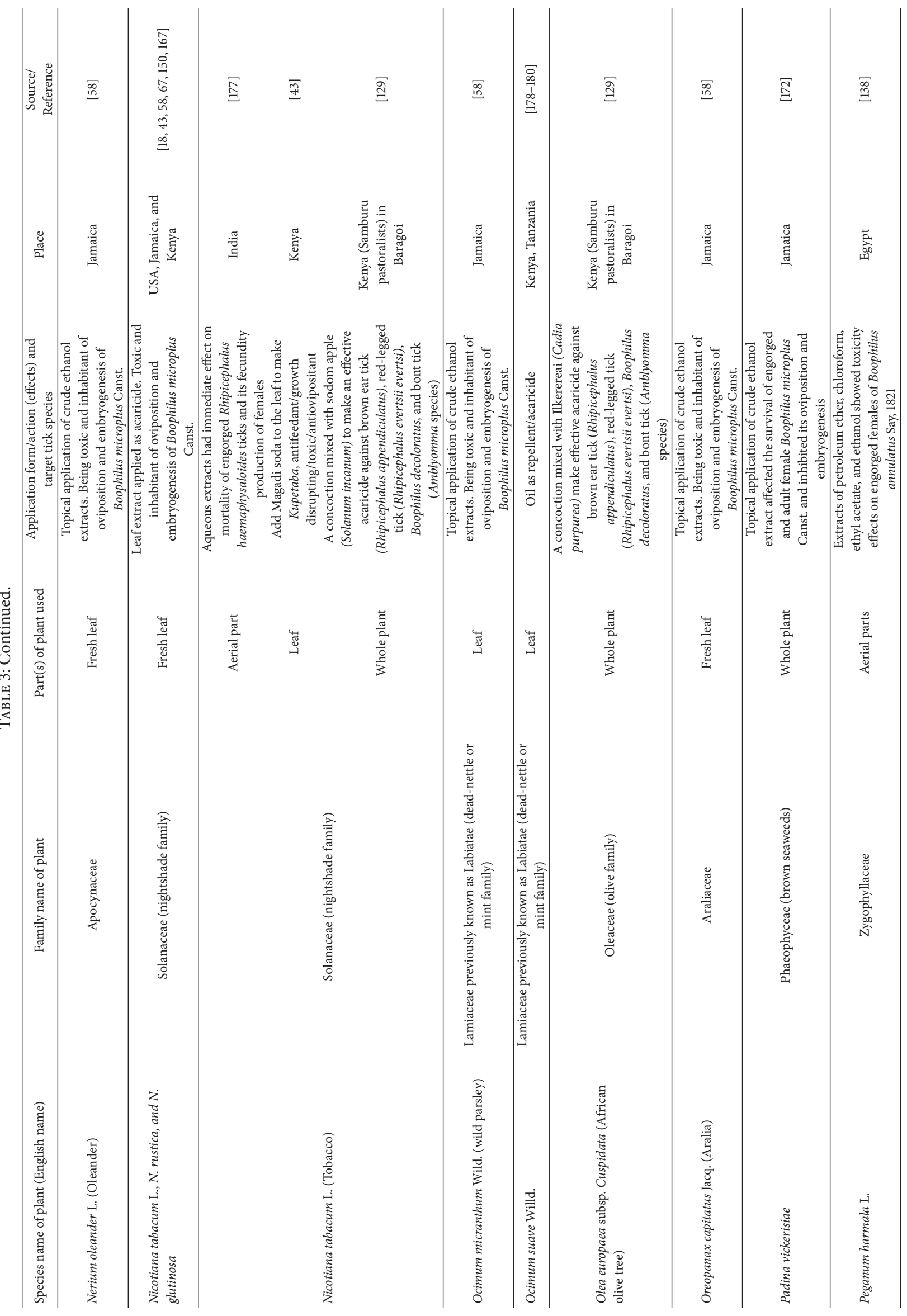




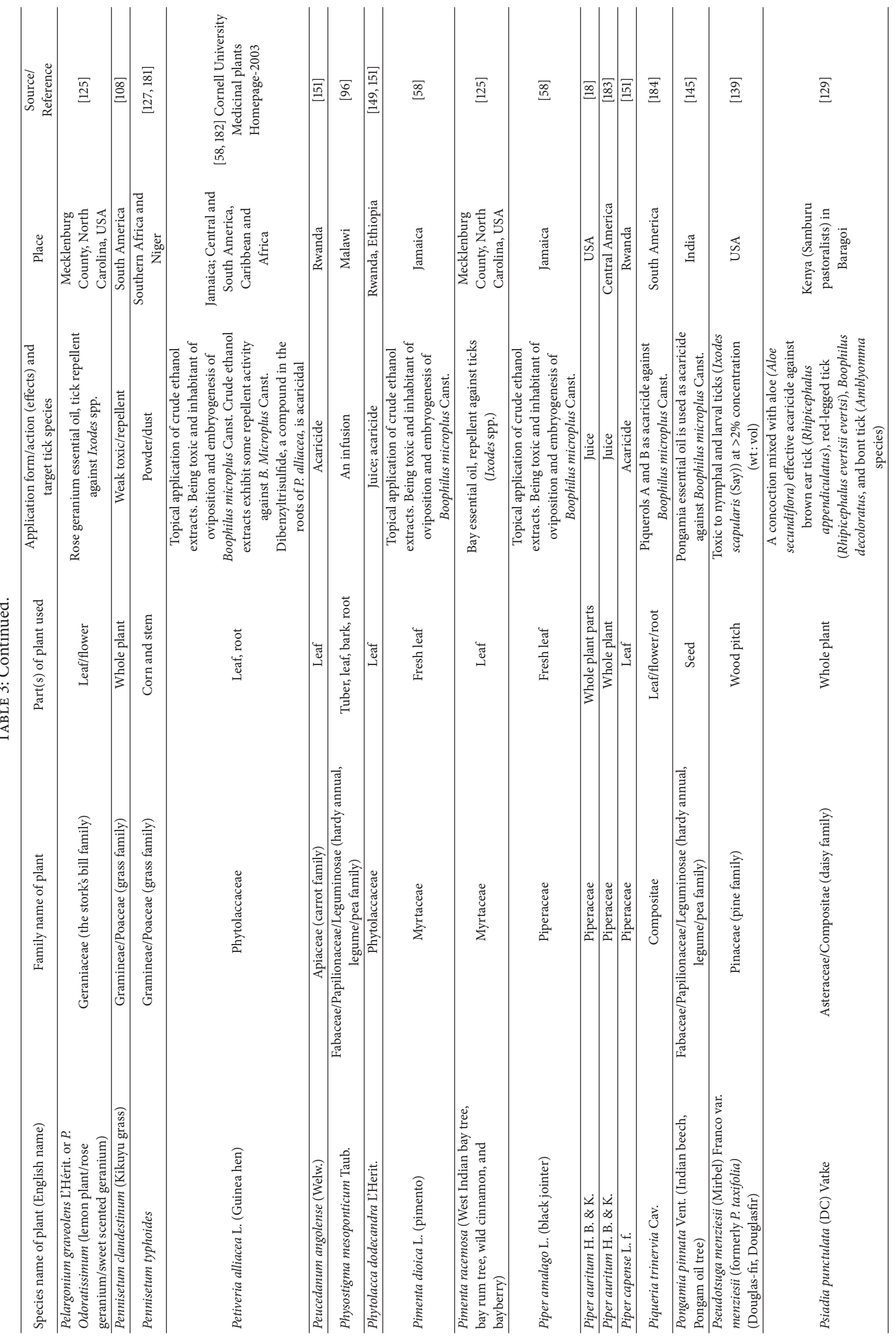




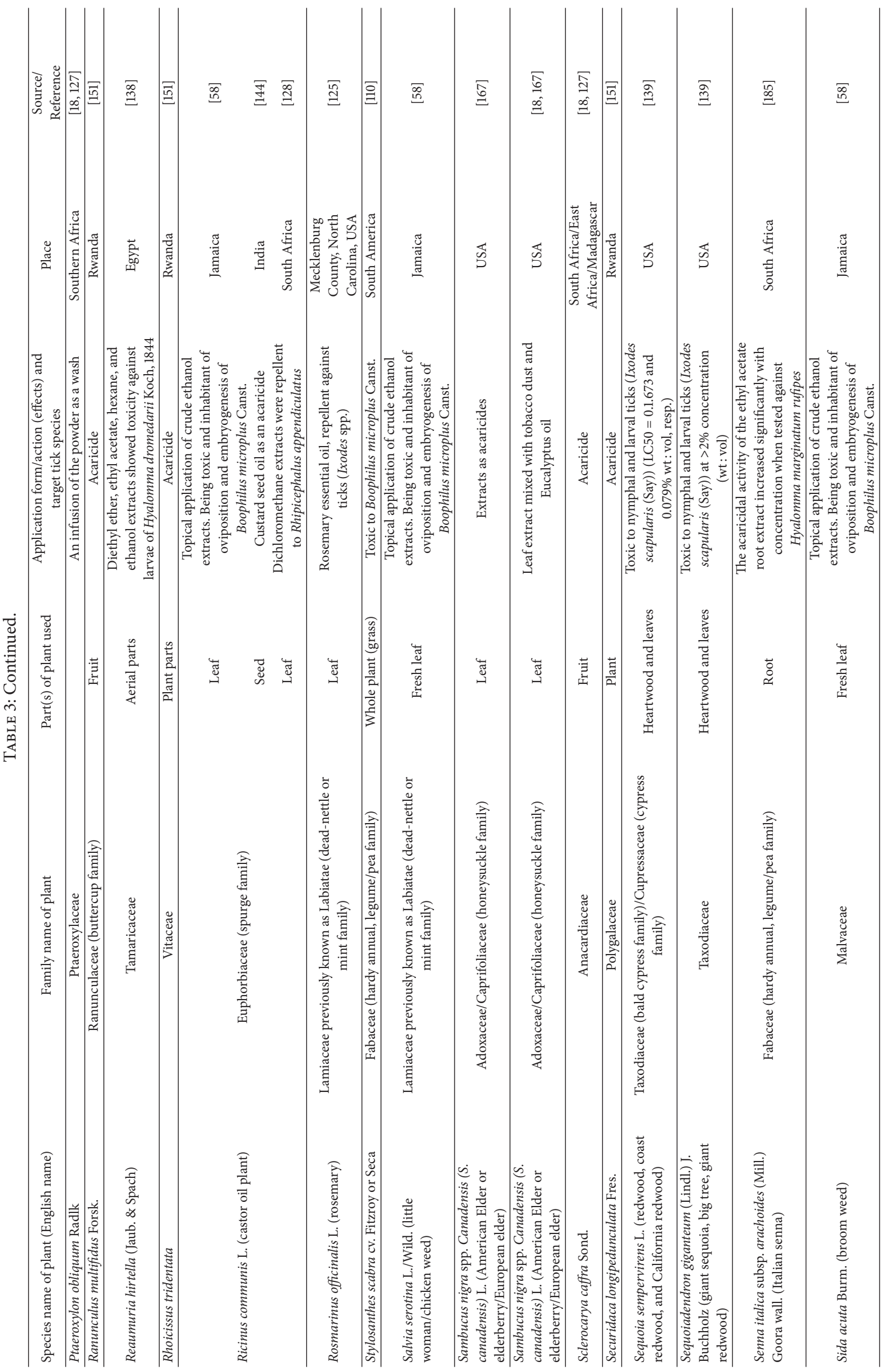




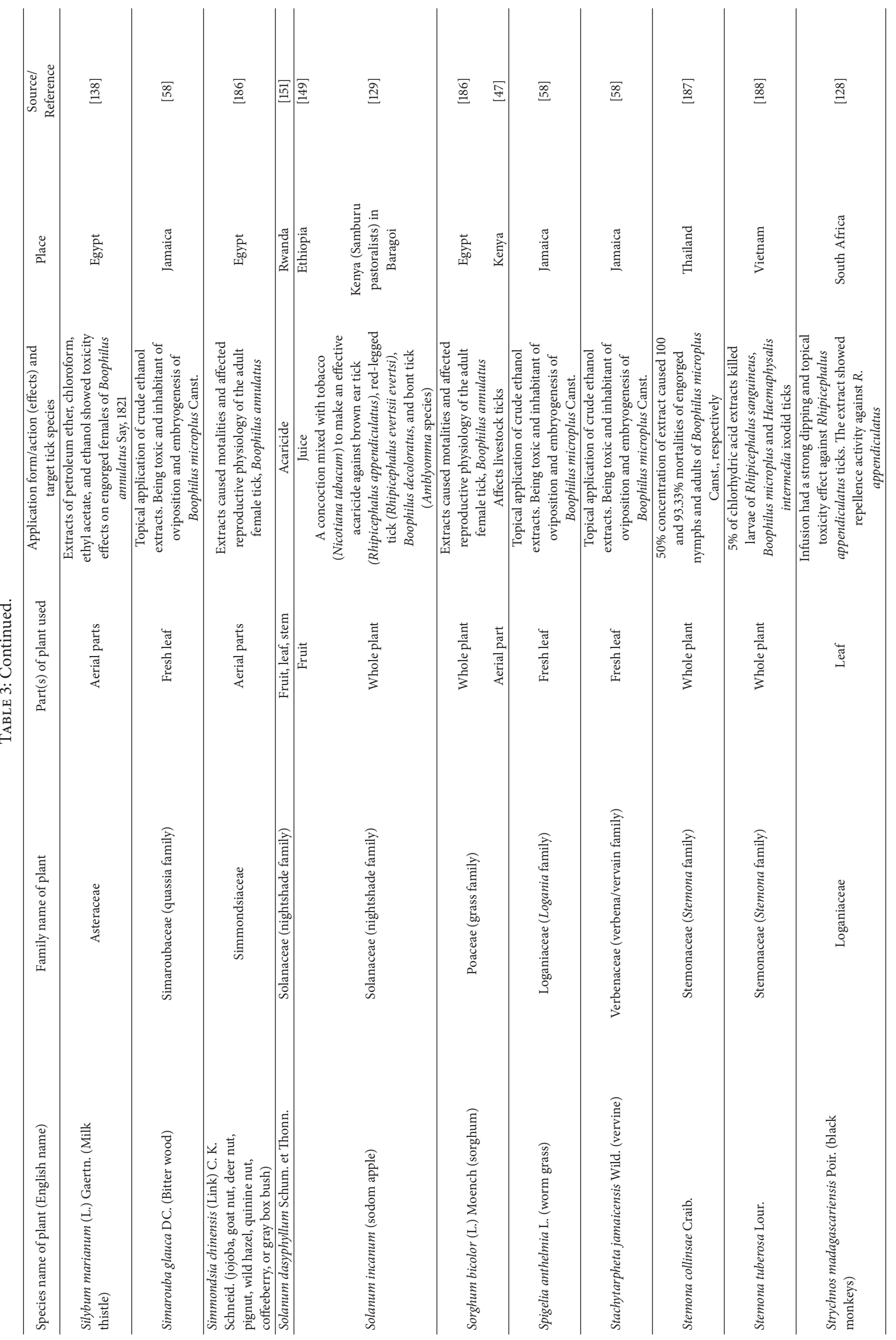




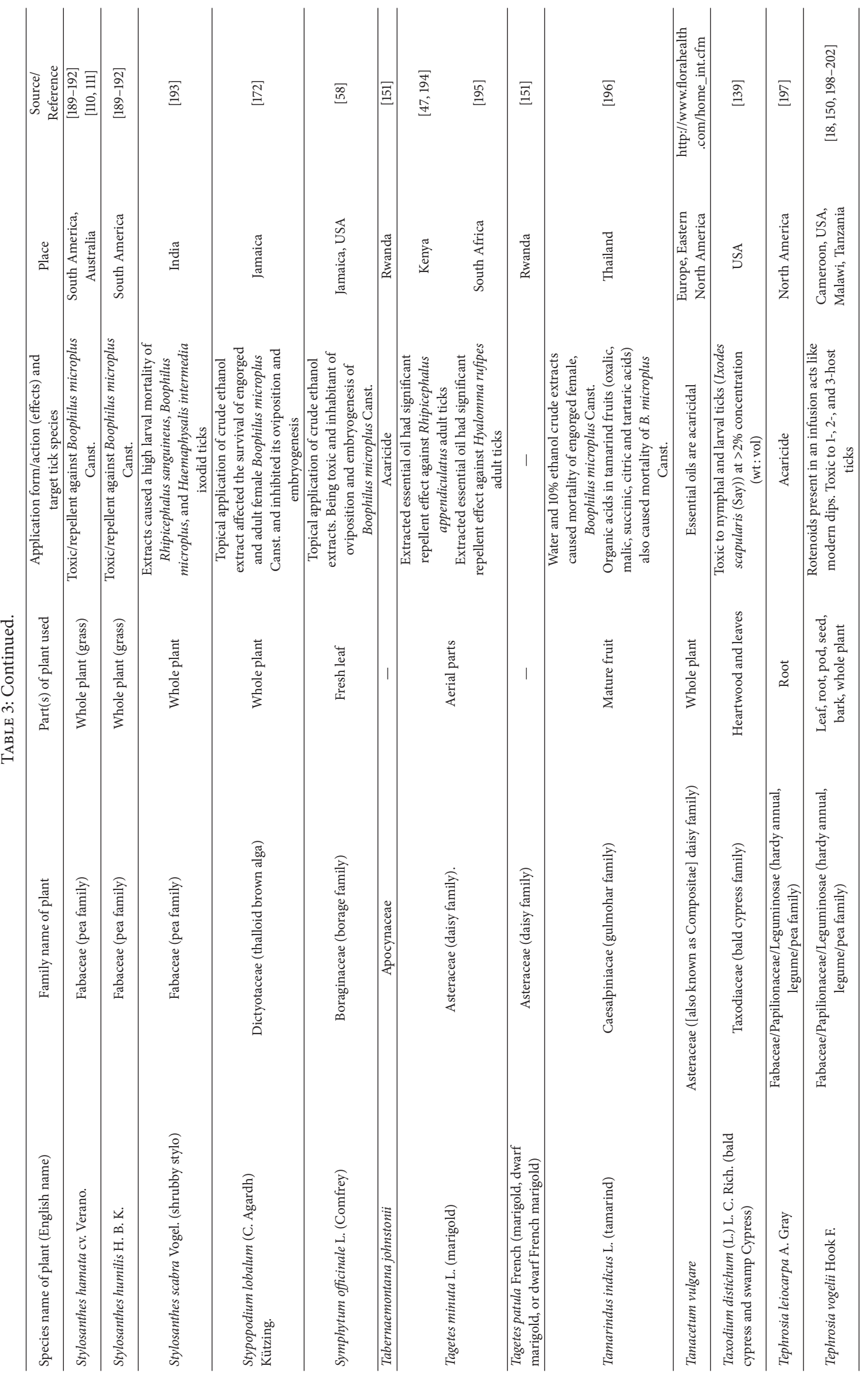




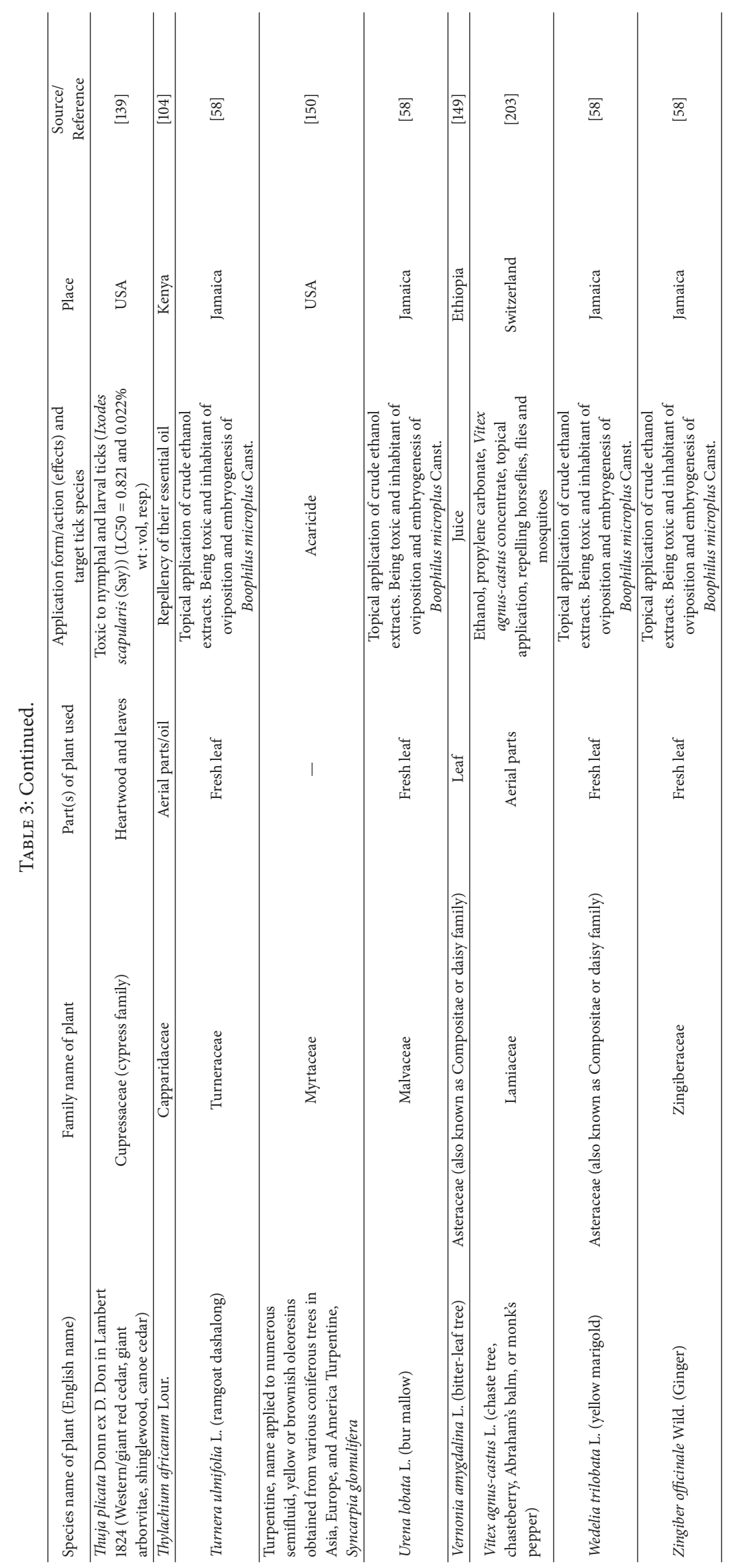


as equal partners in the war against T\&TBDs. However, this is not the case. The rural resource-poor livestock farmers feel that they are being short-changed and exploited during such useful interactions and that their ethnoknowledge may be patented by researchers without their consent and earning any benefits accruing from it on which their entire livelihood is dependent [213]. Bridging this gap of mistrust between ethnopractitioners and researchers poses great challenges and, nevertheless, it remains the biggest stumbling block and threat to any fruitful development of ethnoknowledge in Africa.

Extracts from plants in Table 3 have been shown to possess strong acaricidal and/or tick-repellent bioactivities. Some of the plant extracts are capable of affecting and modifying tick feeding behaviours, molting processes, fecundity, and viability of eggs, and so forth. Some of these plants are suitable forage and due to secondary metabolites they secrete as viscous, adhesive, odorous, or toxic substances; they have been found to be capable of repelling, trapping, and killing different host-seeking tick species [110, 131, 136, 206, 209, 214]. Some plants possess hairs (trichomes) that prevent ticks from climbing to the top in order to attain a suitable posture for attaching to any passing suitable host animal [44]. The existence of plants with these multiple bioactive properties in Africa offers challenges and opportunities to save African countries the high costs for importing acaricides and to replace those rendered unusable with tick resistance by critically considering the possibilities of using indigenous African plants as sources of acaricides [209]. These many bioactive properties indicate that the plants or the resultant herbal products can be integrated in various combinations for the control and management of different tick species especially by rural resource-poor livestock farmers at affordable or no cost at all. For instance, antitick grasses such as $M$. minutiflora and shrubs such as Gynandropsis gynandra and Ocimum suave could be planted in pastures to repel, immobilize, and kill ticks, thus reducing the number of ticks attaching on cattle. This option, in combination with tick attractant shrub, Acalypha fruticosa [122], can be used by rural resource-poor livestock farmers to develop livestock pastures free from tick infestation. Additionally, antitick plants, which serve as forage can also be used in pasture-spelling systems with species suitable for tropical and subtropical regions in an integrated tick management (ITM) control system [33, 108, $132,136,206,209,214]$. On the other hand, botanical extracts (e.g., neem, Kupetaba, G. gynandra, O. suave, M. minutiflora, and $M$. discoidea) would be applied directly on cattle to repel, to disrupt feeding and molting behavioural processes, and to kill the on-host ticks without ticks developing resistance and extracts causing any side effects and environmental pollution. Other traditional methods of tick control and management, for example, hand deticking and intergrazing (grazing sheep ahead of cattle), could also be integrated into the abovementioned management system options. These control strategies would be effective and affordable by many rural resourcepoor livestock farmers in Africa and elsewhere since the seeds of grasses and other antitick plants are inexpensive, locally available, and easily accessible and the technology is simple and easy to apply without the assistance of an external personnel. The technology would also be easily adopted by rural resource-poor livestock farmers since most of them are familiar with the plant materials and are already using one or more of these traditional methods for tick control and management on their farms or within their homesteads (Author's experience in Bukusu and Wanga communities in western Kenya).

Unfortunately, in Africa, there are no commercial uses of these ethnobotanicals and awareness campaigns for their integration into tick control and management systems. The application of ethnobotanicals for tick control and management is still confined to individual rural resource-poor livestock farmers or ethnopractitioners and researchers in their respective institutions. Researchers and rural resource-poor livestock farmers are still independent and closed, each group working on its own without letting the information to benefit either side with critical and open mind. The plants in Table 3 and others yet to be discovered from African communities will only be of value to and benefit African livestock industry if the gap of mistrust between ethnopractitioners and researchers is amicably bridged and the active participation of natural custodians of biodiversity and ethnopractitioners (rural resource-poor livestock farmers) of valuable knowledge is guaranteed in the generation of research focusing on screening programmes dealing with the isolation of bioactive principles and the development of new livestock ectoparasiticides [213].

\section{Potential and Future Prospects for the Use of Antitick Plants in Tick Control and Management}

From the foregoing, the list of antitick plants or plants with acaricidal properties shown in Tables 2 and 3 is not yet exhaustive as more plant species with such activities may be discovered. Efforts to promote hands-on use of antitick plants at community level have clearly increased as signaled by a worldwide documentation of the plants (Tables 2 and 3) and many more studies being conducted on field surveys and trials $[58,109,122,129,149]$ and laboratory tests [73, 96, 215-220]. The ongoing workshops, community-based training seminars, and novel projects on antitick plants at the Intermediate Technology Development Group-Eastern Africa (ITDG-EA), an international nongovernmental organization [129], are other promising proliferation signals in this area. The many ethnoveterinary projects and proposals identified at the November 1997 Pune conference in India signaled a worldwide recognition and appreciation of the potential of EVK in the development of livestock industry [221]. This recent and renewed interest in herbal products as a reemerging animal health aid has been fueled by the rising costs of livelihood-dependent conventional products, their adverse side effects, genetic selection for resistance by target organisms, and continued unavailability in time and quantity to meet the health needs of the growing population. The situation has been exacerbated by continued lack of trained veterinary personnel in remote rural areas and bioprospecting and biopiracy of new herbal products by researchers 
mainly from industrialized societies $[213,222]$. As the focus increasingly concentrates on exploitation of herbal products, the stakeholders should be made aware of the risks involved in and limitations of using these products.

Side effects and toxic reactions to herbal products are considered rare [223-225], albeit their existence being as old as human history [226]. There are claims that toxic effects of herbal products are often not the fault of the herb itself per se but are caused by products containing misidentified plants or contaminants such as bacteria and heavy metals during the preparation of the remedy $[227,228]$. Allergic reactions to herbal products following contact during preparation and or application can occur, as with any other plant material. Toxic problems associated with particular plants or product types are well documented and understood [229-232]. Some plants are inherently toxic, containing naturally occurring toxins, often with cytotoxic or carcinogenic effects. While the identities of the more common toxic plants are generally known, at least to plant phytochemists, older herbal texts may not reflect this knowledge [224].

However, risks involved in using herbal products originate from three main groups of causes. The first group of cause is intrinsic toxicity of several plants that has been outlined since the 1960s [228, 231]. For instance, active ingredient in the antitick and mange castor-oil plant (Ricinus communis), ricin, is very poisonous and provides an example of an EVK agent that must be handled with care while applying to the animal, just like conventional acaricides [233, 234]. The second cause of risks involves herbal products responsible for many dermatitis, psychological, and neurological side effects. While the third one is a result of inconsistence prescription and qualitative and quantitative measures due to ethnicity, culture, picking time, stage of growth, processing, storage, place, and altitude of growth and pollution by other pesticides, and so forth. Other risks include the following: (a) contamination by other plants, botanical confusion, and confusion between two almost similar names such as Stephania tetrandra and Aristolochia fangchi which are, in Chinese, "Han Fang Ji" and "Gang Fang Ji," respectively [231, 235-239]. The confusion may also be induced by (a) same vernacular name for two species, for example, "Copalchi" refers to Coutarea latiflora (not toxic) and Croton niveus (toxic), (b) adulteration by allopathic drugs, (c) circumstances of use, this may result in misuse of herbal products or excessive drenching of animals at times, (d) many unknown factors related to the affected animals' habits/history, and (e) uncontrolled delivery of herbal products via Internet [228]. Some herbal products contain phytochemicals that have strong effects on the animals' body as part of their therapeutic action, that is, purgatives [240]. Highly purified or isolated extracts of plants, such as essential oils or other concentrated isolates, may have markedly different effects on the body or may even be quite toxic compared to less refined extracts of the same herb [241, 242]. Dose-related toxicity is of particular concern with any potent herbal product. As with all acaricides, following the recommended dose guidelines included with all herbal products would be a first line of defense against overdose.
In practice, EVK is not without disadvantages and limitations. Certain particular EVK application methods are often very much localised, harmful, and unhygienic and the scope for their further dissemination is limited. The EVK cures are variable in their effectiveness according to season, method of preparation, ethnicity, person's own experience, and so forth and very few plant products have been validated in the same way in which synthetic drugs must be validated. While some remedies are just inconvenient to prepare or use. From a technical standpoint, some plant products are totally ineffective and acute cases have very little if not nothing to benefit from EVK $[234,243,244]$. One of the most limiting factors of ethnobotanical acaricides is that they are not always practical on a large scale and dosages are uncertain and remedies are not standardized since the concentration of a critical ingredient in a plant often varies from one location to another and from one season to another. A particular EVK method may require considerable amounts of leaves, seeds, or even roots, which might not be possible to get. Further, certain plants are available only at some times of the year and the resource base is ever deteriorating, making ingredients unavailable for preparing products [234].

Although EVK has its limitations, there is tremendous scope for its use in interventions either singly or being integrated with scientific knowledge [245]. EVK practices are often cheap, time-tested, environment-friendly and safe, cost-effective, readily available, location-specific, and based on familiar local resources and strength. Currently, a large segment of the world's livestock population is still dependent on traditional knowledge and ethnoveterinary practices for its healthcare (more than $80 \%$ of the world population relies on it). Many of these ethnopractices offer viable alternatives to conventional western-style animal healthcare and are especially convenient to use and relevant in developing countries with limited financial resources. Local livestock keepers are already familiar with the plant products, which have been effectively and efficiently used over many generations and withstood the test of time. Most of the plant products are freely available or at a cost in proportion to the value of the animal to be treated and are easily administered, usually topically or orally. But unfortunately these ethnopractices are little documented in some cases and increasingly lost through poor storage means and their passage from generation to generation by word of mouth [246]. It is necessary therefore to have extensive documentation, campaign awareness, evaluation, and validation of the EVK and make it more homogeneous, more efficient, less mysterious, and more profitable to holders and users [219]. In addition, an interdisciplinary approach is essential because of the multiplicity of factors and a wide spectrum of techniques and insights (validation, enterprise, environment, health care delivery, public health, education, socioeconomics, sociocultural, networking, planning, and clear policies) involved in $\operatorname{EVK}[48,101]$. There is need therefore for protection and conservation of EVK genetic resources for sustainable utilization and development [99].

With regard to the control and management of ticks and tick-borne diseases using antitick plants, future field and laboratory experiences should target and focus on, at least, the following points: 
(i) Specific target tick species and or related arthropod species that are concerned, namely, the genera Amblyomma, Haemaphysalis, Rhipicephalus, Boophilus, Hyalomma, Dermacentor and Ixodes; mites; biting insects/livestock biting flies; lice; fleas, and so forth

(ii) Whole plant or plant parts/products to be used, namely, barks, leaves, flowers, buds, roots, stems, fruits, seeds, bulbs, juice, latex, gum, sap, and so forth

(iii) The active compounds produced by the plants as well as methods of extraction, isolation, and formulation

(iv) Other products to be associated and integrated with the chosen plant parts' products, namely, soot, salt, soap, soil, charcoal, ash, smoke, dew, any ritual performed, and so forth

(v) Application form, namely, drinking in water, drenching, decoction, infusion, pulverisation, dust, powdered, bolus, paste, juice, poultice, fomentation, compress, rubbing, pour-on, fumigation, hanging bouquet, steaming, and so forth

(vi) Application rate that is the amount of the preparation to apply and the rate of application

(vii) Action being toxic, repellent, acaricidal, antifeedant, antiovipositant, acute and residual effects, and so forth

(viii) Collection and storage of antitick plants by sustainable harvesting of the plants, protection and conservation of the plants, and preservation of harvested and prepared materials

(ix) Simple technologies of processing and applying the preparations, familiar to local resource livestock farmers

(x) Side effects of the preparations being short- and longterm effects

(xi) Whether or not a given preparation is safe for human health

However, scientific validation of promising antitick ethnobotanicals on their efficacy and formulation of packages easily handled by local communities is necessary for a significantly increased use of such remedies, as they will be more feasible, and the results obtained would be more comparable [99]. Consequently, the value of antitick ethnobotanicals will become more easily recognized and understood by professionals from all walks of life in livestock health. However, even when funding for such work is available the researcher is faced with a level of variability that virtually defies control as required in traditional scientific experiments, for example, plant species, time of year of harvesting and growing, growing conditions, method of collection, storage, preparation, and administration [243]. This, however, makes herbal products very unique and thus very difficult to standardize and bring them at the same level as conventional products; hence the term complementary fits them best in their differentiation with synthetic products.

\section{Conclusion}

The antitick ethnobotanical plants offer great potentials in tick control programmes and management strategies. The traditional ways of using such antitick plants in the community can overcome many obstacles such as cost-related production problems, formulation, availability, accessibility, and environmental pollution and contamination. Moreover, their applications are simple and could be used by local communities with minimal external help. In addition, ethnobotanicals are biodegradable, holistic and additive, synergetic, and nutritive in their action and, because of these properties, they do not allow the development of resistance problems like their synthetic counterparts. However, little attention has been given to assess the effectiveness and efficacy of antitick ethnobotanicals in an integrated tick management programmes. For this to be realized, both at local and at global levels, there is need to evaluate the traditional knowledge and explain its scientific rationale where possible with a view to ascertaining safety and preventing abuse so that the "best bets" can be identified for integration into livestock health primary delivery systems. The effectiveness of these "best bets" ethnopractices can be greatest if appropriately blended with conventional technologies and active involvement of the livestock-holding communities. Based on findings of this review article, herbal products will seemingly play a greater role in animal health industry than ever before in this millennium. The impact of this role will be greatest if the active participation of such natural custodians and ethnopractitioners of valuable knowledge is guaranteed in the generation of research focusing on screening programmes dealing with the isolation of bioactive principles and the development of new livestock ectoparasiticides [213].

\section{Conflicts of Interest}

The author declares that there are no conflicts of any interest regarding the publication of this review manuscript in any way.

\section{Acknowledgments}

This review research work is a continuous piece of work, previously supported by the International Foundation for Sciences, Stockholm, Sweden, and the Organization for the Prohibition of Chemical Weapons, The Hague, Netherlands, through Grant AB/12782-2. As a policy requirement of their donor funding, the author wishes to acknowledge them most sincerely for their support, which enabled this review article to be written. The author wishes to acknowledge the studentship stipend and information, computer, and technology (ICT) support received from the International Centre of Insect Physiology and Ecology (ICIPE) under the African Regional for Postgraduate Programmes in Insect Science (ARPPIS) and the Wageningen University and Research Centre, the Laboratory of Entomology, under Ph.D. Sandwich Fellowship. The author wishes to thank the ICIPE staff for their technical support. To them all, the author is very grateful. 


\section{References}

[1] R. G. Titus and J. M. C. Ribeiro, "Salivary gland lysates from the sand fly Lutzomyia longipalpis enhance leishmania infectivity," Science, vol. 239, no. 4845, pp. 1306-1308, 1988.

[2] L. D. Jones, W. R. Kaufman, and P. A. Nuttall, "Modification of the skin feeding site by tick saliva mediates virus transmission," Experientia, vol. 48, no. 8, pp. 779-782, 1992.

[3] E. W. Cupp and M. S. Cupp, "Black Fly (Diptera: Simuliidae) Salivary Secretions: Importance in Vector Competence and Disease," Journal of Medical Entomology, vol. 34, no. 2, pp. 8794, 1997.

[4] N. S. Zeidner, S. Higgs, C. M. Happ, B. J. Beaty, and B. R. Miller, "Mosquito feeding modulates Th1 and Th2 cytokines in flavivirus susceptible mice: An effect mimicked by injection of sialokinins, but not demonstrated in flavivirus resistant mice," Parasite Immunology, vol. 21, no. 1, pp. 35-44, 1999.

[5] G. R. Jani, K. S. Raval, and R. P. Patel, "Ethnomedicine for ectoparasites in buffaloes: a clinical study on mange dermatitis," in Ethnoveterinary Medicine: Alternatives for Livestock Development Proceedings of an International Conference on Validation of Ethnoveterinary Medicine held on November 4-6, 1997, MDMTC, Pune, India, E. Mathias, D. V. Rangnekar, and C. M. McCorkle, Eds., pp. 46-53, BAIF Development Research Foundation, Pune, India, November 1997.

[6] YS. Balashov, "Blodsucking ticks (Ixodoidea)-vectors of disease of man and animals," Miscellaneous Publication of Entomological Society of America, vol. 8, pp. 161-376, 1972.

[7] J. M. C. Ribeiro, "Role of saliva in tick/host interactions," Experimental \& Applied Acarology, vol. 7, no. 1, pp. 15-20, 1989.

[8] J. M. C. Ribeiro, “How ticks make a living," Parasitology Today, vol. 11, no. 3, pp. 91-93, 1995.

[9] S. K. Wikel and D. Bergman, "Tick-host immunology: significant advances and challenging opportunities," Parasitology Today, vol. 13, no. 10, pp. 383-389, 1997.

[10] A. S. Bowman, L. B. Coons, G. R. Needham, and J. R. Sauer, "Tick saliva: recent advances and implications for vector competence," Medical and Veterinary Entomology, vol. 11, no. 3, pp. 277-285, 1997.

[11] “Tick-borne diseases: vector surveillance and control," Technical Information Memorandum. Defense Pest Management Information Analysis Center, Forest Glen Section, Walter Reed Army Medical Center no. 26, Armed Forces Pest Management, Washington, DC, USA, 1998, 2014, http://www.afpmb.org/ pubs/tims/tim26.pdf.

[12] R. D. Gillespie, M. L. Mbow, and R. G. Titus, "The immunomodulatory factors of bloodfeeding arthropod saliva," Parasite Immunology, vol. 22, no. 7, pp. 319-331, 2000.

[13] E. D. Sonenshine, Biology of Ticks, vol. 1 pp. 445, Oxford University Press, New York, NY, USA, 1991.

[14] P. Parola and D. Raoult, "Ticks and tickborne bacterial diseases in humans: an emerging infectious threat," Clinical Infectious Diseases, vol. 32, no. 6, pp. 897-928, 2001.

[15] J. Süss and C. Schrader, "Tick-borne human pathogenic microorganisms found in Europe and those considered nonpathogenic. Part I: Ticks and Viruses," Bundesgesundheitsblatt - Gesundheitsforschung - Gesundheitsschutz, vol. 47, no. 4, pp. 392-404, 2004.

[16] J. S. Gray, "Ticks: their economic importance and methods of control," Outlook on Agriculture, vol. 14, pp. 136-142, 1985.

[17] D. J. Rogers and S. E. Randolph, "Population ecology of tsetse," Review of Entomology, vol. 30, pp. 197-216, 1985.
[18] U. Matzigkeit, Natural Veterinary medicine. Ectoparasites in the Tropics, Weikersheim, Josef Margraf Verlag, Weikersheim, Germany, 1990.

[19] R. McLeod and P. Kristjanson, "Final report of joint esys/ ILRI/ACIAR Tick Cost Project-Economic Impact of Ticks and Tick-Borne Diseases to Livestock in Africa, Asia and Australia," International Livestock Research Institute, 1999.

[20] R. G. Pegram, J. Lemche, H. G. B. Chizyuka et al., "Effect of tick control on liveweight gain of cattle in central Zambia," Medical and Veterinary Entomology, vol. 3, no. 3, pp. 313-320, 1989.

[21] A. M. Alghali, "Component technology development: an integrated tick management approach for livestock production in Africa," International Journal of Tropical Insect Science, vol. 13, no. 4, pp. 609-612, 1992.

[22] M. C. Eisler, S. J. Torr, P. G. Coleman, N. Machila, and J. F. Morton, "Integrated control of vector-borne diseases of livestock-pyrethroids: panacea or poison?" Trends in Parasitology, vol. 19, no. 8, pp. 341-345, 2003.

[23] I. A. R. Norval, D. B. Perry, and S. A. Young, "The epidemiology of theileriosis in africa," p. 481, Academic Press. Harcourt Brace Jovanovich Publishers, New York, NY, USA, 1992.

[24] G. K. Gitau, J. J. McDermott, J. M. Katende, and B. D. Perry, "The epidemiology of theileria parva infections on smallholder dairy farms in Kenya," Annals of the New York Academy of Sciences, vol. 916, pp. 265-270, 2000.

[25] L. H. Makala, P. Mangani, K. Fujisaki, and H. Nagasawa, "The current status of major tick borne diseases in Zambia," Veterinary Research, vol. 34, no. 1, pp. 27-45, 2003.

[26] I. A. R. Norval, "Arguments against intensive dipping," Zimbwbwe Veterinary Journal, vol. 14, pp. 19-25, 1983.

[27] A. S. Young, C. M. Groocock, and D. P. Kariuki, "Integrated control of ticks and tick-borne diseases of cattle in Africa," Parasitology, vol. 96, no. 2, pp. 403-432, 1988.

[28] A. W. Mukhebi, J. Curry, D. B. Perry et al., "Economic impact of theileriosis and its control in Africa," in ILRI links: Biosciences Programme: Epidemiology and disease control (project 7), 1993, 2009.

[29] J. E. Frisch, "Towards a permanent solution for controlling cattle ticks," International Journal for Parasitology, vol. 29, no. 1, pp. 57-71, 1999.

[30] J. Okello-Onen, E. M. Tukahirwa, B. D. Perry et al., "Population dynamics of ticks on indigenous cattle in a pastoral dry to semi-arid rangeland zone of Uganda," Experimental and Applied Acarology, vol. 23, no. 1, pp. 79-88, 1999.

[31] J. A. Hogsette, "Management of ectoparasites with biological control organisms," International Journal for Parasitology, vol. 29, no. 1, pp. 147-151, 1999.

[32] J. H. Pruett, "Immunological control of arthropod ectoparasites - A review," International Journal for Parasitology, vol. 29, no. 1, pp. 25-32, 1999.

[33] G. R. Pegram, J. R. Tatchell, J. J. de Castro et al., Tick Control: New Concepts, World Animal Review, FAO, Viale delle Terme di Caracalla, Rome, Itally, 1993.

[34] D. L. Berkvens, G. M. D. Eysen, and B. A. R. J. Bandt, "Sustainable tick and tickborne disease control in livestock improvement in developing countries," Veterinary Parasitology, vol. 77, pp. 211-215, 1998.

[35] J. M. Olwoch, C. J. D. W. Rautenbach, B. F. N. Erasmus, F. A. Engelbrecht, and A. S. Van Jaarsveld, "Simulating ticks distributions over sub-Saharan Africa: the use of observed and simulated climate surfaces," Journal of Biogeography, vol. 30, no. 8, pp. 1221-1232, 2003. 
[36] J. M. Burridge, "Attractant pheromone for the cayenne tick identified," in College of Veterinary Medicine, University of Florida, Institute of Food and Agricultural Science, CSREES Tropical and Subtropical Agriculture Research, Gainesville, Fla, USa, June 2009.

[37] R. G. Pegram, D. David Wilson, and J. W. Hansen, "Past and present national tick control programs: why they succeed or fail," Annals of the New York Academy of Sciences, vol. 916, pp. 546-554, 2000.

[38] N. F. White and P. Rowlinson, "Observation on the use of both modern veterinary and traditional treatments by samburu pastoralists in Northern Kenya," in Ethnoveterinary Medicine: Alternatives for Livestock Development. Proceedings of an International Conference on Validation of Ethnoveterinary Medicine, E. Mathias, D. V. Rangnekar, and C. M. McCorkle, Eds., BAIF Development Research Foundation, Pune, India, 1997.

[39] E. Mathias-Mundy and M. C. McCorkle, "Ethnoveterinary medicine: an annotated bibliography. bibliographies in technology and social change," Technology and Social Change Programme no. 6, Iowa State University, Ames, Iowa, USA, 1989.

[40] K. K. Prah and P. A. Okeyo, "The role of social science in generating technologies for the farming community in Africa," Insect Science and Its Application, vol. 10, no. 06, pp. 777-782, 1989.

[41] J. W. Ssennyonga, "Working with farmers to develop integrated tick management," Insect Science and Its Application, vol. 13, no. 4, pp. 599-606, 1992.

[42] J. E. George, "Present and future technologies for tick control," Annals of the New York Academy of Sciences, vol. 916, pp. 583588, 2000.

[43] O. O. Dipeolu and J. N. Ndungu, "Acaricidal activity of kupetaba, a ground mixture of natural products, against Rhipicephalus appendiculatus," Veterinary Parasitology, vol. 38, no. 4, pp. 327-338, 1991.

[44] M. M. Malonza, O. O. Dipeolu, A. O. Amoo, and S. M. Hassan, "Laboratory and field observations on anti-tick properties of the plant Gynandropsis gynandra (L.) brig," Veterinary Parasitology, vol. 42, no. 1-2, pp. 123-136, 1992.

[45] E. N. Mwangi, "The role of women in animal husbandry: the kenyan perspective," in Livestock Production and Diseases in the Tropics: Livestock production and human welfare. Proceedings of the VIII International Conference of Institutions of Tropical Veterinary Medicine, H. K. Zessin, Ed., Deutsche stiftung füf Internationale Entwicklung, Zentralstelle für Ernährung und Landwirtschaft, Feldafing, Germany, 1996.

[46] G. P. Kaaya and R. C. Saxena, "Evaluation of neem products for the control of the African ticks Rhipicephalus appendiculatus, Amblyomma variegatum, and Boophilus decoloratus," ICIPE Annual Scientific Report, vol. 1998, pp. 165-167, 1995-1997.

[47] W. Wanzala, W. Takken, W. R. Mukabana, A. O. Pala, and A. Hassanali, "Ethnoknowledge of Bukusu community on livestock tick prevention and control in Bungoma district, western Kenya," Journal of Ethnopharmacology, vol. 140, no. 2, pp. 298324, 2012.

[48] "Ethnoveterinary medicine: an annotated bibliography of community animal healthcare," in Intermediate Technology Development Group (ITDG), M. Martin, E. Mathias, and C. M. McCorkle, Eds., Intermediate Technology Publications, Practical Actions, London, UK, 2001.

[49] M. O. Odindo, "Pest and vector management in Africa," International Journal of Tropical Insect Science, vol. 12, no. 5-6, pp. 527-533, 1991.
[50] C. de Haan and L. D. Umali, "Public and private sector roles in the supply of veterinary services," in Proceedings of the 12th Agricultural Sector Symposium. In: Public and private sector roles in agricultural development, J. R. Anderson and C. de Haan, Eds., pp. 125-137, The World Bank, New York, NY, USA, 1992.

[51] S. Holden, "The economics of the delivery of veterinary services," Revue Scientifique Et Technique, vol. 18, no. 2, pp. 425439, 1999.

[52] F. E. Cerrate de, Plantas que curan las heridas del hombre y los animals, vol. 3, no. 4, pp. 1-12, 1980.

[53] T. W. Schillhorn van Veen, "Sense or nonsense? Traditional methods of animal parasitic disease control," Veterinary Parasitology, vol. 71, no. 2-3, pp. 177-194, 1997.

[54] W. M. Kofi-Tsekpo and D. W. Kioy, "Newer direction of plant drug research: the need to examine and investigate traditional remedies for pharmacotheraphy of animal and zoonotic diseases," African Journal of Health Sciences, vol. 5, pp. 12-14, 1998.

[55] C. Lans, Creole remedies: Case studies of ethnoveterinary medicine in Trinidad and Tobago [Ph.D. thesis], Wageningen University and Research Centre, Wageningen, The Netherlands, 2001.

[56] C. Lans, Natural Pest Control. Country Story Overview. Template.gif, vol. 23, Department of Sociology, University of Victoria, British Columbia, Canada, 2010.

[57] S. C. Rawlins and A. Mansingh, "Relative susceptibility of Jamaican strains of Boophilus microplus, Amblyomma cajennense, and Anocentor nitens to various acaricides," Journal of Economic Entomology, vol. 70, no. 6, pp. 607-608, 1977.

[58] A. Mansingh and L. A. D. Williams, "Pesticidal potential of tropical plants: ii. acaricidal activity of crude extracts of several Jamaican plants," Insect Science and its Application, vol. 18, no. 2, pp. 149-155, 1998.

[59] M. F. Ashley-Montagu, Witchcraft, Oracles and Magic among the Azande and the Nuer People of the Southern Sudan and Congo, vol. 28, 22 Page, The Monograph. Oxford, UK, 1938.

[60] K. Wolfgang, An ethno-veterinary study of cattle health care by Fulße herders of south central Upper Volta. Thesis, Hampshire College, Amherst, Mass, USA, 1983.

[61] W. Marx, "Traditionelle tierärtliche heilmethoden unter besonderer berücksichtigung der kauterrisation in somalie. beiträge der klini schen veterinärmedizin zur verbesserung der tierischen erzeugung in den tropen. giessener beiträge zur entwicklungsforschung," Wissenschaftliches Zentrum Tropeninstitut, Justus-Liebig-Universität Giessen, vol. 10, no. 1, pp. 111-116, 1984.

[62] S. Buchanam, "Zoopharmacognosy, Animal Self-Medication. Outline for CE Paper, EN 570," Tech. Rep., 2002, 2010, http:// www.colostate.edu/Depts/Entomology/courses/en570/papers_ 2002/buchanan.htm.

[63] M. A. Ibrahim, N. Nwude, O. Y. Aliu, and A. R. Ogunsusi, "Traditional concepts of animal disease and treatment among Fulani herdsmen in Kaduna State of Nigeria," Pastoral Development Network 16c, Agricultural Administration Unit, Overseas Development Institute (ODI), Regent's College, London, UK, 1983.

[64] C. W. Schwabe, "Cattle, priests and progress in medicine," in Wesley W. Spink Lectures on Comparative Medicine, vol. 4, pp. 1076-1076, University of Minnesota Press, Minneapolis, Minn, USA, 1979.

[65] V. N. Viswanatha Reddy, B. K. Narainswami, and K. N. Nomesh, "Holistic approach of treating animals, selected papers. file 3 of 
9: part 2," in Ethnoveterinary Medicine: Alternatives for Livestock Development. Proceedings of an International Conference on Validation of Ethnoveterinary Medicine held on November 1997, MDMTC, Pune, India, E. Mathias, D. V. Rangnekar, and C. M. McCorkle, Eds., vol. 1, pp. 46-53, BAIF Development Research Foundation, Pune, India, 1998.

[66] M. S. Bah, "Observations on disease problems and traditional remedies relating to the use of work oxen in the Karina area. Report on a pilot study of preparation for the research project," The Health and Management of N'Dama cattle in Sierra Leone, with special reference to the use of work Oxen in village conditions 1, pp. 12, Sierra Leone Work Oxen Project, Freetown, Sierra Leone, 1983.

[67] ITDG and IIRR, "Ethnoveterinary medicine in Kenya: a field manual of traditional animal health care practices," Intermediate Technology Development Group (ITDG) and International Institute of Rural Reconstruction (IIRR), Nairobi, Kenya, 1996.

[68] K. Wolfgang and A. Sollod, "Traditionary veterinary medical practice by Twareg herders in Central Niger," Integrated livestock Project, Ministry of Animal Resources, Tahoua, Niger, 1986, pp 29.

[69] JA. Lira, Medicina andina: Farmacopea Y ritual. Centro de Estudios Rurales Andinos "Bartolomé de las casas," Cuzco, Perú. 1985.

[70] D. N. Pande, "Efficacy of herbal preparation pestoban in control of ectoparasites in household pets and domesticated animals," Indian Journal of Indigenous Medicines, vol. 7, no. 1, pp. 51-54, 1990.

[71] D. K. Maske, N. G. Bhilegaonkar, and C. R. Jangde, “Treatment of tick infestation in cattle with pestoban," Indian Journal of Indigenous Medicines, vol. 17, pp. 81-83, 1996.

[72] N. Chungsamarnyart, S. Jiwajinda, W. Jansawan, U. Kaewsuwan, and P. Burnasilpin, "Effective plant crude-extracts on the tick (Boophilus microplus) larvicidal action," Kasetsart Journal of Natural Science, vol. 22, pp. 37-41, 1988.

[73] N. Chungsamarnyart, C. Ratanakreetakul, and Jansawan W., "Acaricidal activity of the combination of plant crude-extracts to tropical cattle ticks," Kasetsart Journal of Natural Science, vol. 28, no. 4, pp. 649-660, 1994.

[74] K. Ravindra, P. P. S. Chauhan, R. D. Agrawal, S. Daya, R. Kumar, and D. Shankar, "Efficacy of herbal ectoparasiticide AV/EPP/14 against lice and tick infestation on buffalo and cattle," Journal of Veterinary Parasitology, vol. 14, pp. 67-69, 2000.

[75] Law R., The Horse in The West African History: The Role of The Horse in The Societies of Pre-Colonial Africa, Oxford University Press, Oxford, UK, 1980.

[76] L. A. Kimball, "Brunei Malay traditional ethno-veterinary practices," Borneo Research Bulletin, vol. 17, no. 2, pp. 123-150, 1985.

[77] PPEA-PRATEC, Proyecto Piloto de Ecosistemas Andinos Y Proyecto Andino de Tecnologías Campesinas (PPEAPRATEC). Manejo campesino de semillas en los Andes. Serie Eventos de Técnicos. No Publisher given, Lima, Perú. 1989.

[78] G. Pompa, Medicamentos indígenas: Coleccion extraída de los reinos vegetal, animal $Y$ mineral-índice para sus aplicaciones (51 ${ }^{\text {st }}$ edition). Corporación Marca, Caracas, Venezuela, for Editorial América. 1984.

[79] D. Sautier and H. Amaral, "Integrated pest management or integrated system management?" in Proceedings of the workshop on alternatives to pesticides, held in a village in "Minas Gerais" (central Brazil), Brazil, 1989, http://www.metafro.be/leisa/1989/ 5-3-6.pdf.
[80] C. M. Moscoso, Secretos medicinales de la flora peruana Y guía de la maternidad. 2nd edition. Tipografía Americana, Cuzco, Perú. 1953.

[81] H. Valdizán and A. Maldonado, "La medicina popular peruana: Contribución al folklore médico del Preú," in Imprenta Torres Aguirre for the Consejo Indio de Sud-America, vol. 3, Lima, Perú, 1985.

[82] R. G. Mares, "Animal husbandry, animal industry and animal disease in the Somaliland protectorate. Part II," British Veterinary Journal, vol. 110, no. 11, pp. 470-481, 1954.

[83] W. Wagner, Die chinesische Landwirtschaft, Paul Parey, Berlin, Germany, 1926.

[84] S. Gourlet, Les plantes en médecine veterinaire populaire. Vétérinary Science [Doctoral, thesis], Université Paul-Sabatier, Toulouse, France, 1979.

[85] C. M. McCorkle, "Management of animal health and disease in an indigenous Andean community," Tech. Rep. 4, Small Ruminant Collaborative Research Suport Programme, Department of Rural Sociology, University of Missouri-Columbia, Columbia, Mo, USA, 1982.

[86] C. V. Bustinza and S. S. Viveros, "Formas de tratamiento tradicional de la sarna de alpacas," in Proyecto piel de alpaca: Informe final, C. Victor Bustinza and et al, Eds., pp. 80-84, Universitdad Nacional del Altiplano (UNA), Instituto de Investigaciones para el Desarrollo Social del Altiplano (IIDSA), Convenio UNANUFFIC, Puno, Peru, Puno, Perú, 1985.

[87] J. Casaverde, Calendario alpaquero. Minka. 1985; 16: 18.

[88] R. F. Palacios, “Tecnologia del pastoreo," in La tecnologia en el mundo andino: Runakunap kawsayninkupaq rurasqankunaqa TomoI:Subsistencia y mensuracion, pp. 217-232, mprenta Universitaria de la Universitdad Nacional dAutonoma de Mexico, Mexico DF, Mexico, 1985.

[89] R. F. Palacios, "Tecnologia del manejo de pastizales y rebanos," in Llamichos y pagocheros: pastores de llamas y alpacas, pp. 87100, Editorial Universitaria UNSAAC for the Centro de Estudios Andinos Cuzco, Cuzco, Peru, 1988.

[90] H. J. Tillman, Planificar el futuro de la comunidad. Minka. 1983; 11: 21-25.

[91] C. E. Avila, C. V. Bustinza, and R. Sapana, "Alternativas de tratamiento de la sarna de alpacas," in Proyecto piel de alpaca: Informe final, C. Victor Bustinza and et al, Eds., pp. 9098, Universitdad Nacional del Altiplano (UNA), Instituto de Investigaciones para el Desarrollo Social del Altiplano (IIDSA), Convenio UNA-NUFFIC, Puno, Peru, Puno, Perú, 1985.

[92] C. Devakumar and B. Subramanyam, "Exploration of the Indian flora for insect control agents," in Proceedings of the International Symposium, on "Utilization of Natural Product in Developing Countries: Trends and Needs" held at the Natural Products Institute, University of the West Indies, Kingston, Jamaica, 2000.

[93] D. M. O. Akabwai, J. C. Mariner, J. Toyang, A. Berhano, S. Django, and T. Osire, "Ethnoveterinary knowledge: a bias for community-based animal health work in pastoral areas," The Kenya Veterinarian, vol. 18, 520 pages, 1994.

[94] ITDG, "Ethnoveterinary Research and Development," in Intermediate Technology Development Group (ITDG), C. M. McCorkle, E. Mathias, and T. W. Schillhorn van Veen, Eds., vol. 1, Intermediate Technology Publications, London, UK, 1996.

[95] J. B. Wanyama, Confidently Used Ethnoveterinary Knowledge Among Pastoralists of Samburu, Kenya. Book One: Methodology 
and Results. Book Two: Preparation and Administration, Intermediate Technology Development Group (ITDG), Intermediate Technology Publications, Nairobi, Kenya, 1997.

[96] D. M. B. Kambewa, W. M. Mfitilodze, K. Hüttner, A. B. C. Wollny, and D. K. R. Phoya, "The use of indigenous veterinary remedies in Malawi, Selected Papers. File 3 of 9: Part 2. In: Ethnoveterinary Medicine: Alternatives for Livestock Development," in Proceedings of an International Conference on Validation of Ethnoveterinary Medicine held on November 4-6, 1997 in Pune, India, E. Mathias, D. V. Rangnekar, and C. M. McCorkle, Eds., vol. 1, BAIF Development Research Foundation, Pune, India, 1998, in Pune, India (Edited by.

[97] E. Mathias, D. V. Rangnekar, and C. M. McCorkle, "Ethnoveterinary Medicine: Alternatives for Livestock Development, Selected Papers. File 3 of 9: Part 2," in Proceedings of an International Conference on Validation of Ethnoveterinary Medicine held on November 4-6, 1997 in Pune, India, E. Mathias, D. V. Rangnekar, and C. M. McCorkle, Eds., vol. 1, BAIF Development Research Foundation, Pune, India, 1998, in Pune, India (Edited by.

[98] ITDG-EA, "The role of community-based animal health care in rural development," in Intermediate Technology Development Group-East Africa (ITDG-EA), M. M. Kagiko, J. Kajume, E. Tong'i, and W. Ngugi, Eds., Intermediate Technology Publications, Nairobi, Kenya, 2001.

[99] E. F. Guèye, "Newcastle disease in family poultry: Prospects for its control through ethnoveterinary medicine," in Livestock Research for Rural Development. Proceedings of the 27th World Veterinary Congress, T. R. Preston, P. Penh, and R. Sansoucy, Eds., vol. 14, pp. 25-29, Tunis, Tunisia, 5 edition, 25-29 September 2002.

[100] "Research, Publications and Highlights," in Community-based Animal Health and Participatory Epidemiology Unit (CAPE), Pan African Programme for the Control of Epizootics (PACE), A. Catley, Ed., African Union/InterAfrican Bureau for Animal Resources (AU/IBAR), Nairobi, Kenya, 2003.

[101] J. M. Saxena, "Present status of ethnoveterinary research and development, Selected Papers. File 3 of 9: Part 2," in Ethnoveterinary Medicine: Alternatives for Livestock Development. Proceedings of an International Conference on Validation of Ethnoveterinary Medicine held on November 4-6, 1997, MDMTC, Pune, India, C. M. McCorkle, E. Mathias, and T. W. S. van Veen, Eds., vol. 1, BAIF Development Research Foundation, Pune, India, 1998.

[102] Anonymous, "The Preface," in The preface. Proceedings of the International Symposium on Utilization of Natural Products in Developing Countries: "Trends and Needs", held in July 10-14, 2000 at the University of the West Indies, A. Mansingh, R. Young, T. Yee et al., Eds., vol. 1, The University Printry, UWI, Kingston, Jamaica, 2002.

[103] A. Hassanali and W. Lwande, "Antipest secondary metabolites from African plants," American Chemical Society, no. 387, pp. 79-94, 1989.

[104] B. Torto and A. Hassanali, "Progress in the search for antiarthropod botanicals," Recent Research Developments in Phytochemistry, vol. 1, pp. 475-488, 1997.

[105] D. M. Chavunduka, "Plants regarded by Africans as being of medicinal value to animals," Rhodesian Veterinary Journal, vol. 7, no. 1, pp. 6-12, 1976.

[106] D. M. Chavunduka, "Delivery of animal health and production services-general aspects," in Advancing agricultural production in Africa. Proceeding of CAB's First Scientific Conference, D. L. Hawksworth, Ed., vol. 30, pp. 262-266, Arusha, Tanzania, 1984.
[107] R. Menendenz, "El Melinitus minutifloraay la garrapata," Revista de Agricultura de Puerto Rico, vol. 4, pp. 219-223, 1924.

[108] K. C. Thompson, J. E. Roa, and T. N. Romero, "Anti-tick grasses as the basis for developing practical tropical tick control packages," Tropical Animal Health and Production, vol. 10, no. 1, pp. 179-182, 1978.

[109] O. O. Dipeolu, A. O. Mongi, D. K. Punya, A. A. Latif, O. A. Amoo, and Odhiambo T. R., "Current concepts and approach to control of livestock ticks in Africa," Discovery and Innovation, vol. 4, pp. 35-44, 1992.

[110] R. W. Sutherst, R. J. Jones, and H. J. Schnitzerling, "Tropical legumes of the genus: Stylosanthes and their ability to immobilize and kill cattle ticks," Nature, vol. 295, pp. 320-321, 1982.

[111] R. H. Zimmerman, G. I. Garris, and J. S. Beaver, "Potential of Stylosanthes plants as a component in an integrated pest management approach to tick control," Preventive Veterinary Medicine, vol. 2, no. 1-4, pp. 579-588, 1984.

[112] R. W. Sutherst and L. J. Wilson, "Tropical legumes and their ability to immobilize and kill cattle ticks," in Insects and the Plants Surface, B. E. Juniper and T. R. E. Ssouthwood, Eds., pp. 185-194, Edward Arnold, 1986.

[113] L. J. Wilson and R. W. Sutherst, "Acceptability of Stylosanthes scabra vogel as a substrate for larvae of Boophilus microplus (Canestrini) (Acarina: Ixodidae)," Australian Journal of Entomology, vol. 25, no. 4, pp. 353-358, 1986.

[114] R. W. Sutherst, L. J. Wilson, R. Reid, and J. D. Kerr, "A survey of the ability of tropical legumes in the genus stylosanthes to trap larvae of the cattle tick, boophilus microplus (Ixodidae)," Australian Journal of Experimental Agriculture, vol. 28, no. 4, pp. 473-479, 1988.

[115] L. J. Wilson, R. W. Sutherst, and J. D. Kerr, “Trapping of larvae of the cattle tick Boophilus microplus by Stylosanthes scabra under grazing conditions," Australian Journal of Agricultural Research, vol. 40, no. 6, pp. 1301-1308, 1989.

[116] A. Maradufu, "Furanosesquiterpenoids of Commiphora erythraea and C. myrrh," Phytochemistry, vol. 21, no. 3, pp. 677-680, 1982.

[117] H. J. Beentje, Kenya Trees, Shrubs and Lianas, Narural Museums of Kenya, Nairobi, Kenya, 1994.

[118] M. Ndungu, W. Lwande, A. Hassanali, L. Moreka, and S. C. Chhabra, "Cleome monophylla essential oil and its constituents as tick (Rhipicephalus appendiculatus) and maize weevil (Sitophilus zeamais) repellents," Entomologia Experimentalis et Applicata, vol. 76, no. 3, pp. 217-222, 1995.

[119] E. N. Mwangi, S. Essuman, G. P. Kaaya, E. Nyandat, D. Munyinyi, and M. G. Kimondo, "Repellence of the tick Rhipicephalus appendiculatus by the grass Melinis minutiflora," Tropical Animal Health and Production, vol. 27, no. 4, pp. 211216, 1995.

[120] W. Lwande, A. J. Ndakala, A. Hassanali et al., "Gynandropsis gynandra essential oil and its constituents as tick (Rhipicephalus appendiculatus) repellents," Phytochemistry, vol. 50, no. 3, pp. 401-405, 1998.

[121] E. N. Mwangi, S. M. Hassan, G. P. Kaaya, and S. Essuman, “The impact of Ixodiphagus hookeri, a tick parasitoid, on Amblyomma variegatum (Acari: Ixodidae) in a field trial in Kenya," Experimental and Applied Acarology, vol. 21, no. 2, pp. 117-126, 1997.

[122] S. M. Hassan, O. O. Dipeolu, and M. M. Malonza, "Natural attraction of livestock ticks by the leaves of a shrub," Tropical Animal Health and Production, vol. 26, no. 2, pp. 87-91, 1994. 
[123] M. Jacobson, Insecticides from plants, no. 154, USDA Handbook, Washington DC, USA, 1958.

[124] V. S. Mironov, "Sweet Flag (Acorus calamus) as insecticide and repellent," Medicins kaja parazitologija I parazitarnye bolezni, vol. 9, pp. 409-410, 1940.

[125] B. B. Annie, “Tick Repellent. Healthy Living Channels. Secret Herbal Tick Repellent Formula 2005," 2013, http://www.care2 .com/channels/solutions/self/23.

[126] T. E. Pamo, F. Tendonkeng, J. R. Kana, G. Tenekeu, L. A. Tapondjou, and V. K. Payne, "The acaricidal effect of the essential oil of Ageratum houstonianum Mill. flowers on ticks (Rhipicephalus lunulatus) in Cameroon," South African Journal of Animal Science, vol. 34, no. 1, pp. 244-247, 2004.

[127] J. M. Watt and M. G. Breyer-Brandwijk, The Medicinal and Poisonous Plants of Southern and Eastern Africa. Being an account of their medicinal and other uses, chemical composition, pharmacological effects and toxicology in man and animal, E \& S Livingstone Ltd, Edinburgh Scotland, 2nd edition, 1962.

[128] K. G. Mawela, The toxicity and repellent properties of plant extracts used in ethnoveterinary medicine to control ticks [MSc. Thesis], University of Pretoria, Pretoria, South Africa, 2008.

[129] G. Akall, "Herbs known only to pastoralists," in Technology Development Group-East Africa (ITDG-EA), Intermediate Technology Publication, Nairobi, Kenya, 2009.

[130] E. Aycardi, E. Benavides, O. Garcia, G. Mateus, F. Henao, and F. N. Zuluaga, "Boophilus microplus tick burdens on grazing cattle in Colombia," Tropical Animal Health and Production, vol. 16, no. 2, pp. 78-84, 1984.

[131] A. M. Thadeu, A. Barros De, and E. D. Evans, "Acao de gramineas forrageiras em larvas infestantes do carrapato dos bovidos Boophilus microplus," Pesquisa Veterinária Brasileira é Pesqui, vol. 9, pp. 17-21, 1989.

[132] C. M. Brizuela, C. A. Ortellado, T. I. Sanchez, O. Osorio, and A. R. Walker, "Formulation of integrated control of Boophilus microplus in Paraguay: Analysis of natural infestations," Veterinary Parasitology, vol. 63, no. 1-2, pp. 95-108, 1996.

[133] C. Cruz-Vazquez and M. Fernańdez-Ruvalcaba, "Anti-tick repellent effect of Andropogon gayanus grass on plots of different ages experimentally infested with Boophilus microplus larvae," Parasitologia al Dia, vol. 24, no. 3-4, pp. 88-91, 2000.

[134] M. Fernandez-Ruvalcaba, P. F. Torre, C. Cruz-Vazquez, and Z. Garcia-Vazquez, "Anti-tick effects of Melinis minutiflora and Andropogon gayanus grasses on plots experimentally infested with Boophilus microplus larvae," Experimental and Applied Acarology, vol. 32, no. 4, pp. 293-299, 2004.

[135] P. C. Standley, Trees and Shrubs of Mexico, Smithsonian Press, Washington DC, USA, 1920.

[136] L. A. D. Williams, "Adverse effects of extracts of artocarpus altilis park, and azadirachta indica (A. juss) on the reproductive physiology of the adult female tick, boophilus microplus (canest.)," Invertebrate Reproduction and Development, vol. 23, no. 2-3, pp. 159-164, 1993.

[137] H. Chiasson, A. Bélanger, N. Bostanian, C. Vincent, and A. Poliquin, "Acaricidal properties of Artemisia absinthium and Tanacetum vulgare (Asteraceae) essential oils obtained by three methods of extraction," Journal of Economic Entomology, vol. 94, no. 1, pp. 167-171, 2001.

[138] S. Abdel-Shafy, M. M. M. Soliman, and S. M. Habeeb, "In vitro acaricidal effect of some crude extracts and essential oils of wild plants against certain tick species," Acarologia, vol. 47, no. 1-2, pp. 33-42, 2007.
[139] N. A. Panella, J. Karchesy, G. O. Maupin, J. C. S. Malan, and J. Piesman, "Susceptibility of Immature Ixodes scapularis (Acari: Ixodidae) to plant-derived acaricides," Journal of Medical Entomology, vol. 34, no. 3, pp. 340-345, 1997.

[140] ICIPE, "International Centre of Insect Physiology and Ecology (ICIPE)," in Proceedings of the 5th Scientific Annual Report, Nairobi, Kenya, 1998/99.

[141] P. A. Ndumu, J. B. D. George, and M. K. Choudhury, "Toxicity of neem seed oil (Azadiracta indica) against the larvae of Amblyomma variegatum, a three-host tick in cattle," Phytotherapy Research, vol. 13, no. 6, pp. 532-534, 1999.

[142] S. Abdel-Shafy and A. A. Zayed, "In vitro acaricidal effect of plant extract of neem seed oil (Azadirachta indica) on egg, immature, and adult stages of Hyalomma anatolicum excavatum (Ixodoidea: Ixodidae)," Veterinary Parasitology, vol. 106, no. 1, pp. 89-96, 2002.

[143] D. H. Al-Rajhy, A. M. Alahmed, H. I. Hussein, and S. M. Kheir, "Acaricidal effects of cardiac glycosides, azadirachtin and neem oil against the camel tick, Hyalomma dromedarii (Acari: Ixodidae)," Pest Management Science, vol. 59, no. 11, pp. 12501254, 2003.

[144] B. Kalakumar, H. S. A. Kumar, B. A. Kumar, and K. S. Reddy, "Evaluation of custard seed oil and neem oil as acaricides," Journal of Veterinary Parasitology, vol. 14, pp. 171-172, 2000.

[145] S. Sivaramakrishnan, N. S. Kumar, D. Jeyabalan, R. Babu, N. S. Raja, and K. Murugan, "The effect of mixtures of neem, eucalyptus and pongamia oils on the mortality and biochemical profiles of the tick, Boophilus microplus (Canestrini) (Acari: Ixodidae)," Indian Journal of Environment and Toxicology, vol. 6, pp. 85-86, 1996.

[146] P. K. Gupta, G. Shashi, and M. H. Khan, "Preliminary evaluation of neem based formulations against Boophilus microplus (Boophilus) microplus," Indian Journal of Environment and Toxicology, vol. 8, pp. 89-90, 1998.

[147] O. E. Benavides, M. G. Hernandez, N. A. Romero, A. H. Castro, and B. J. L. Rodriguez, "Preliminary evaluation of neem (Azadirachta indica) extracts as alternative for cattle tick Boophilus microplus control," Revista Colombiana de Entomologia, vol. 27, pp. 1-8, 2001.

[148] H. F. Nagaty, M. A. Rifaat, and T. A. Morsy, "The latex of Calotropis procera (family: Asclepiadeceae), a new substance having an ascaricidal effect in-vitro," The Journal of the Egyptian Medical Association, vol. 42, pp. 563-566, 1959.

[149] A. Regassa, "The use of herbal preparations for tick control in western Ethiopia," Journal of the South African Veterinary Association, vol. 71, no. 4, pp. 240-243, 2000.

[150] R. Cremlyn, Pesticides-Preparation and Mode of Action, 72 pages, J. Wiley and Sons Limited, New York, NY, USA, 1978.

[151] L. Van Puyvelde, D. Geysen, F.-X. Ayobangira, E. Hakizamungu, A. Nshimiyimana, and A. Kalisa, "Screening of medicinal plants of rwanda for acaricidal activity," Journal of Ethnopharmacology, vol. 13, no. 2, pp. 209-215, 1985.

[152] J. A. Duke and R. Vasquez, Amazonian Ethnobotanical Dictionary, CRC Press, Inc, Boca Raton, Fla, USA, 1994.

[153] J. R. Timberlake, Ethnobotany of the Pokot of Northern Kenya. East African Herbarium, Nairobi. Center for Economic Botany, Royal Botanic Gardens, London, UK, 1987.

[154] Rutgers Cooperative Extension. If Plants Could Talk: Preventing Ticks Bites: A Gardening Television Series. Rutgers, The State University of New Jersey. Cook College and The New Jersey Agricultural Experiment Station 2001, 2009. 
[155] M. W. Ndungu, S. C. Chhabra, and W. Lwande, "Cleome hirta essential oil as livestock tick (Rhipicephalus appendiculatus) and maize weevil (Sitophilus zeamais) repellent," Fitoterapia, vol. 70, no. 5, pp. 514-516, 1999.

[156] A. Maradufu and J. D. Warthen Jr., "Furanosesquiterpenoids from Commiphora myrrh oil," Plant Science, vol. 57, no. 2, pp. 181-184, 1988.

[157] J. F. Carroll, A. Maradufu, and J. D. Warthen, "An extract of Commiphora erythraea: a repellent and toxicant against ticks," Entomologia Experimentalis et Applicata, vol. 53, no. 2, pp. 111116, 1989.

[158] L. Rimbach, "Traditional methods of treating cattle diseases," Studiennaufenthalte in Afrika, Asien und Latein-Amerika, 1977.

[159] A. M. Massoud, M. A. Kutkat, S. Abdel Shafy, R. M. El-Khateeb, and I. M. Labib, "Acaricidal efficacy of Myrrh (Commiphora molmol) on the fowl tick Argas persicus (Acari: Argasidae).," Journal of the Egyptian Society of Parasitology, vol. 35, no. 2, pp. 667-686, 2005.

[160] Anonnymous, "Aromansi - Natural Care (Animal Care products) with Nature's Essential Oils 2005," 2009.

[161] S. J. E. T. Aitchison, "On the flora of the Kuram valleym etc, Afghanistan," Journal of the linnean society, vol. 18, 1881.

[162] R. N. Chopra, R. L. Badhwar, and S. L. Nayar, "Insecticidal and piscicidal plants of India," Journal of the Bombay Natural History Society, vol. 42, no. 4, pp. 854-902, 1941.

[163] Madaus G., Lehrbuch der biologischen Heilmittel, Abt. I: Heilpflanzen, Bd. II. Georg Thieme Verlag, Leipzig. 1938.

[164] A. Schmidt and A. Marcus, "Der Tropenpflanzer," Berlin, vol. 44, 178 pages, 1941.

[165] M. M. J. Minja, "Medicinal plants used in the promotion of animal health in Tanzania," Scientific and Technical Review of the Office International des Epizooties, vol. 13, no. 3, pp. 905-925, 1994.

[166] P. Wilkin, "A revision of the compound-leaved Yams (Dioscorea, Dioscoreaceae) of Africa," Kew Bulletin, vol. 54, no. 1, pp. 19-39, 1990.

[167] de. Bairachi Levy Juliette, The complete herbal handbook for farm and stable, Faber \& Faber, Limited, London, UK, 3rd edition, 1984.

[168] J. F. Morton, Atlas of medicinal plants of middle America. Bahamas to Yucatan, vol. 6, Springfield, Ill, USA, 1981.

[169] J. E. Simon, A. F. Chadwick, and L. E. Craker, Herbs: An Indexed Bibliography. 1971-1980. The Scientific Literature on Selected Herbs, and Aromatic and Medicinal Plants of the Temperate Zone, Archon Books, Hamden, CT, USA, 1984.

[170] G. Davis, "Gaiam-Strategies for Safer Pest Control," http://www .gaiam.com/retail/gai_content/learn/gai_learnArticlePrint.asp.

[171] R. B. R. Porter, P. B. Reese, L. A. D. Williams, and D. J. Williams, "Acaricidal and insecticidal activities of cadina-4,10 (15)-dien3-one," Phytochemistry, vol. 40, no. 3, pp. 735-738, 1995.

[172] L. A. Williams, "Acaricidal activity of five marine algae extracts on female boophilus microplus (Acari: Ixodidae)," The Florida Entomologist, vol. 74, no. 3, pp. 404-408, 1991.

[173] H. K. Plank, "Experiments with mamey for pests of man and animals," Tropical Agriculture, vol. 27, pp. 38-41, 1950.

[174] G. P. Kaaya, E. N. Mwangi, and M. M. Malonza, "Acaricidal activity of Margaritaria discoidea (Euphorbiaceae) plant extracts against the ticks Rhipicephalus appendiculatus and Amblyomma variegatum (Ixodidae)," International Journal of Acarology, vol. 21, no. 2, pp. 123-129, 1995.
[175] L. M. F. Borges, P. H. Ferri, W. J. Silva, W. C. Silva, and J. G. Silva, "In vitro efficacy of extracts of Melia azedarach against the tick Boophilus microplus," Medical and Veterinary Entomology, vol. 17, no. 2, pp. 228-231, 2003.

[176] L. Hernandez, D. Parra, and A. Ahumada, "Repellent and acaricidal actvity of the oil and some chromatographic fractions of the grass Melinis minutiflora against Boophilus microplus," Revista Colombiana de Ciencias Quimico-Farmaceuticas, vol. 17, pp. 45-50, 1990.

[177] R. K. Choudhary, C. Vasanthi, B. R. Latha, and L. John, "In vitro effect of Nicotiana tabacum aqueous extract on Rhipicephalus haemaphysaloides ticks," Indian Journal of Animal Sciences, vol. 74, no. 7, pp. 730-731, 2004.

[178] J. B. Chogo and G. Crank, "Chemical composition and biological activity of the Tanzanian plant Ocimum suave," Journal of Natural Products, vol. 44, no. 3, pp. 308-311, 1981.

[179] E. N. Mwangi, A. Hassanali, S. Essuman, E. Myandat, L. Moreka, and M. Kimondo, "Repellent and acaricidal properties of Ocimum suave against Rhipicephalus appendiculatus ticks," Experimental and Applied Acarology, vol. 19, no. 1, pp. 11-18, 1995.

[180] A. Hassanali, W. Lwande, N. Ole-Sitayo, L. Moreka, S. Nokoe, and A. Chapya, "Weevil repellent constituents of Ocimum suave leaves and Eugenia caryophyllata cloves used as grain protectants in parts of Eastern Africa," Discovery and Innovation, vol. 2, no. 2, pp. 91-95, 1990.

[181] H. Puffet, "Fharmacopée vétérinaire traditionnelle des éleveurs du Sud-Niger," Troyicultwa, vol. 3, pp. 14-15, 1985.

[182] L. Johnson, L. A. D. Williams, and E. V. Roberts, "An insecticidal and acaricidal polysulfide metabolite from the roots of Petiveria alliacea," Pesticide Science, vol. 50, no. 3, pp. 228-232, 1997.

[183] S. Altschul and R. Von, Drugs and Foods from Little-Known Plants. Notes in Harvard University Herbaria, Harvard University Press, London, England, 1973.

[184] M. P. Gonzalez-de la, D. Chavez-Peña, M. Jimenez-Estrada, and C. Ramos-Mundo, "Acaricidal potential of piquerols A and B against," Journal of Pesticide Science, vol. 33, no. 1, pp. 73-80, 1991.

[185] S. R. Magano, K. M. Thembo, S. M. Ndlovu, and N. F. H. Makhubela, "The anti-tick properties of the root extracts of Senna italica subsp. arachoides," African Journal of Biotechnology, vol. 7, no. 4, pp. 476-481, 2008.

[186] O. Kandil, M. S. Habeeb, and I. M. M. Nasser, "Adverse effect of Sorghum bicolour, Sea anemone, Cynobacteria spp. and Simmondsia chiinensis (Hohoba) extracts on reproductive physiology of the adult female tick, Boophilus annulatusannulatus," Assiut Veterinary Medical Journal, vol. 42, no. 83, pp. 29-37, 1999.

[187] W. Jansawan, S. Jittapalapong, and N. Nongnuch Jantaraj, "Effect of Stemona collinsae extract aganist cattle ticks (Boophilus microplus," Journal: Natural Science, vol. 27, no. 3, pp. 336340, 1993.

[188] B. T. Tho, "Study on pharmaceutical effects of stemone extract on animal ectoparasites and clinical trial results," Veterinary Association of Hanoi, Vietnam, vol. 10, no. 1, pp. 58-63, 2013.

[189] C. Cruz-Vazquez, M. Fernandez-Ruvalcaba, C. J. Solano, and V. Z. Garcia, "Anti-tick effect observed in mature plants of tropical legumes, Stylosanthes humilis and Stylosanthes hamata," Parasitologia al Dia, vol. 23, no. 1-2, pp. 15-18, 1999.

[190] M. Fernandez-Ruvalcaba, C. Cruz-Vazquez, J. Solano-Vergara, and Z. Garcia-Vazquez, "Anti-tick effects of Stylosanthes humilis and Stylosanthes hamata on plots experimentally 
infested with Boophilus microplus larvae in Morelos, Mexico," Experimental and Applied Acarology, vol. 23, no. 2, pp. 171-175, 1999.

[191] M. Fernández-Ruvalcaba, C. Cruz-Vazquez, Z. García-Vazquez, and O. J. Saltijeral, "Estudio de seguimiento del efecto antigarrapata de las leguminosas tropicales, Stylosanthes humilis (L.) Stylosanthes hamata (L.) de un anõ de edad," Tecnica Pecuaria en Mexico, vol. 37, pp. 51-56, 1999.

[192] F. M. Castrejón, C. Cruz-vázquez, M. Fernández-Ruvalcaba, J. Molina-Torres, J. S. Cruz, and M. R. Parra, "Repellence of Boophilus microplus larvae in Stylosanthes humilis and Stylosanthes hamata plants," Parasitologia Latinoamericana, vol. 58, pp. 118-121, 2003.

[193] M. D. Khudrathulla and M. S. Jagannath, "Biocontrol of ixodid ticks by forage legume Stylosanthes scabra (Vogel)," Indian Journal of Animal Sciences, vol. 68, pp. 428-430, 1998.

[194] W. Wanzala, "Ethnobotanicals for management of the brown ear tick, Rhipicephalus appendiculatus in western Kenya," in Wageningen University and Research Centre, p. 231, Ponsen \& Looijen, Wageningen, The Netherlands, 2009.

[195] F. Nchu, S. R. Magano, and J. N. Eloff, "In vitro anti-tick properties of the essential oil of Tagetes minuta L. (Asteraceae) on Hyalomma rufipes (Acari: Ixodidae)," Onderstepoort Journal of Veterinary Research, vol. 79, no. 1, pp. 1-5, 2012.

[196] N. Chungsamarnyart and W. Jansawan, "Effect of Tamarindus indicus L. against the Boophilus microplus," Kasetsart Journal: Natural Science, vol. 35, no. 1, pp. 34-39, 2001.

[197] C. Pennington, The tarahumar of Mexico. Their environment and material culture, University Utah Press, Salt Lake City, Utah, USA, 1963.

[198] A. Niang, “Contribution à l'étude de la Pharmacopée traditionnelle mauritanienne. Thése pour le doctorat en médecine vétérináire," Tech. Rep., Ecole Nationale de Médecine vétérináire, SIDI THABET, Tunisie, 1987.

[199] B. M. Kambewa, M. W. Mfitilodze, K. Huttner, C. B. A. Wollny, and R. K. D. Phoya, "The use of indigenous veterinary remedies in Malawi," in Validation of Ethno-veterinary medicine alternatives for livestock development. Proceedings of an International Conference on Validation of Ethnoveterinary Medicine held on November 4-6, 1997, MDMTC, Pune, India, E. Mathias, D. V. Rangnekar, and C. M. McCorkle, Eds., BAIF Development Research Foundation , Pune, India, 1998.

[200] G. J. Lemmens and P. J. Fryer, Insecticides, sheep-dip, animalwash and the like. United States patent. 1,242, 954 and 1,242,955. Patented Oct. 16. 1917.

[201] Bertram T. M. O. S. B., St. Benedict's Abbey, P.O. Peramiho, Tanzania-East Africa. 1988.

[202] M. S. Habeeb, "Ethno-veterinary and medicinal knowledge of crude plant extracts and its methods of application (traditional and modern) for tick control," World Applied Sciences Journal, vol. 11, no. 9, pp. 1047-2010, 2010.

[203] H. Mehlhorn, G. Schmahl, M. Frese, I. Mevissen, A. Harder, and K. Krieger, "Effects of a combination of emodepside and praziquantel on parasites of reptiles and rodents," Parasitology Research, vol. 97, no. 1, pp. S65-S69, 2005.

[204] A. E. Sollod, K. Wolfgang, and J. A. Knight, "Veterinary anthropology: Interdisciplinary methods in pastoral systems research," in Livestock development in sub-Saharan Africa: Constraints, prospects, policy, J. R. Simpson and P. Evangelou, Eds., p. 8, Westview Press, Boulder, CO, USA, 1984.

[205] C. W. Schwabe and I. M. Kuojok, "Practices and beliefs of the traditional Dinka healer in relation to provision of modern medical and veterinary services for the Southern Sudan," Human Organization, vol. 40, no. 3, pp. 231-238, 1981.

[206] G. P. Kaaya, "Status and recent advances in tick management," Insect Science and its Application, vol. 13, pp. 587-594, 1992.

[207] M. M. J. Minja, "Utilisation of Medicinal Plants in Veterinary Practice," in Proceedings of the Second Tanzania Veterinary Association Scientific Conference, Arusha, Tanzania, 1984.

[208] M. M. J. Minja, “The Maasai wonder plants," in Proceedings of the People and Plants Training Workshop held at the Tropical Pesticides Research Institute (TPRI), 15-18 March 1999.

[209] G. P. Kayaa, “The potential for antitick plants as components of an integrated tick control strategy," Annals of the New York Academy of Sciences, vol. 916, pp. 576-582, 2000.

[210] A. O. Adekunle, I. O. Oladele, and D. T. Olukaiyeja, "Indigenous control methods for pests and diseases of cattle in Northern Nigeria," Livestock Research for Rural Development, vol. 14, no. 2, 2002.

[211] J. W. Chiera, R. M. Newson, and A. Maradufu, "Anti-tick properties of molasses grass, Melinis minutiflora," ICIPE Fifth Annual Scientific Report, 1977.

[212] G. P. Kaaya and R. C. Saxena, "Evaluation of effects of ingested neem seed powder on tick attachment, feeding and reproduction,” ICIPE Annual Scientific Report, 1998.

[213] L. Hoareau and J. E. DaSilva, "Medicinal plants: a re-emerging health aid," Electronic Journal of Biotechnology, vol. 2, no. 2, 1999.

[214] G. P. Kaaya, "Non-chemical agents and factors capable of regulating tick populations in nature: a mini review," International Journal of Tropical Insect Science, vol. 13, pp. 587-594, 1992.

[215] H. P. Bayemi, "Laboratory trial on the efficacy of indigenous acaricides on the Boophilus decoloratus in Cameroon, Selected Papers. File 3 of 9: Part 2," in Ethnoveterinary Medicine: Alternatives for Livestock Development. Proceedings of an International Conference on Validation of Ethnoveterinary Medicine held on November 4-6, 1997, MDMTC, Pune, India, E. Mathias, D. V. Rangnekar, and C. M. McCorkle, Eds., BAIF Development Research Foundation, Pune, India, 1998.

[216] P. U. Desai, "Effect of Annona squamosa seed preparations on house flies, Selected Papers. File 3 of 9: Part 2," in Ethnoveterinary Medicine: Alternatives for Livestock Development. Proceedings of an International Conference on Validation of Ethnoveterinary Medicine held on November 4-6, 1997, MDMTC, Pune, India, E. Mathias, D. V. Rangnekar, and C. M. McCorkle, Eds., vol. 1, BAIF Development Research Foundation, Pune, India, 1998.

[217] N. P. Dakshinkar and D. B. Sarode, "Therapeutic evaluation of crude extracts of indigenous plants against mange of dogs, Selected Papers. File 3 of 9: Part 2," in Ethnoveterinary Medicine: Alternatives for Livestock Development. Proceedings of an International Conference on Validation of Ethnoveterinary Medicine held on November 4-6, 1997, MDMTC, Pune, India, E. Mathias, D. V. Rangnekar, and C. M. McCorkle, Eds., vol. 1, BAIF Development Research Foundation, Pune, India, 1998.

[218] M. A. Thaker, K. S. Bhavsar, G. J. Sarvaiya, K. R. Mishra, and P. M. Verma, "Oral toxicity of oil of Annona squamosa in chicken, Selected Papers. File 3 of 9: Part 2," in Ethnoveterinary Medicine: Alternatives for Livestock Development. Proceedings of an International Conference on Validation of Ethnoveterinary Medicine held on November 4-6, 1997, MDMTC, Pune, India, E. Mathias, D. V. Rangnekar, and C. M. McCorkle, Eds., vol. 1, BAIF Development Research Foundation, Pune, India, 1998.

[219] M. M. J. Minja, Status of IK integration in the development process in Tanzania with particular focus on the validation 
of ethnoveterinary practices: lessons and experiences. Paper Presented at the Regional Workshop on Indigenous Knowledge, 2002.

[220] G. R. Jani, K. S. Raval, and R. P. Patel, "Ethnomedicine for ectoparasites in buffaloes: a clinical study on mange dermatitis, Selected Papers. File 3 of 9: Part 2,' in Ethnoveterinary Medicine: Alternatives for Livestock Development. Proceedings of an International Conference on Validation of Ethnoveterinary Medicine held on November 4-6, 1997 in Pune, India, E. Mathias, D. V. Rangnekar, and C. M. McCorkle, Eds., vol. 1, BAIF Development Research Foundation, Pune, India, 1998.

[221] N. J. Toyang, M. Nuwanyakpa, C. Ndi, S. Django, and W. C. Kinyuy, "Ethnoveterinary medicine practices in the Northwest Province of Cameroon," Indigenous Knowledge and Development Monitor, vol. 3, no. 3, 24 pages, 1995.

[222] N. K. Bhattarai, "Folk use of plants in veterinary medicine in Central Nepal," Fitoterapia, vol. 63, no. 6, pp. 497-506, 1992.

[223] G. Koren, S. Randor, S. Martin, and D. Danneman, "Maternal Ginseng Use Associated With Neonatal Androgenization," JAMA: The Journal of the American Medical Association, vol. 264, no. 22, p. 2866, 1990.

[224] E. Yarnell and L. Meserole, "Toxic botanicals: Is the poison in the plant or its regulation?" Alternative and Complementary Therapies, vol. 3, no. 1, pp. 13-19, 1997.

[225] A. Shulman, "Toxicological problems of traditional remedies and food supplements," International Journal of Alternative Complementary Medicine, vol. 3, no. 2, pp. 56-57, 1997.

[226] R. Le Strange, Ed., A History of Herbal Plants, Angus and Robertson Publishers, London, UK, 1st edition, 1977.

[227] I. S. Humphrey and J. D. McKenna, "Herbs and Breastfeeding," Breastfeeding Medicine, vol. 17, no. 2, pp. 11-12, 1997.

[228] A. Caubet, E. Le Bayon, D. Tripodi, and J. P. Curtes, "Herbal medicine and toxic risk," European Journal of Emergency Medicine, vol. 8, no. 1, 73 pages, 2001.

[229] O. J. Kokwaro, Medicinal Plants of East Africa, East African Literature Bereau. General Printers Limited, Nairobi, Kenya, 2nd edition, 1993.

[230] M. Wichtl, Herbal Drugs and Phytopharmaceuticals: A Handbook for Practice on a Scientific Basis, RC Press, Boca Raton, Fla, USA, 1994.

[231] E. Röder, "Medicinal plants in Europe containing pyrrolizidine alkaloids," Pharmazie, vol. 50, pp. 83-98, 1995.

[232] A. Y. Leung and S. Foster, Encyclopedia of Common Natural Ingredients Used in Foods, Drugs, and Cosmetics, John Wiley \& Sons, New York, NY, USA, 2nd edition, 1996.

[233] C. Peacock, Improving Goat Production in the Tropics - A Manual for Development Workers, Oxfam, Oxford, UK, 1996.

[234] Mathias E., "Limitations and strength of ethnoveterinary medicine," in Introducing ethnoveterinary medicine, 2001, http:// www.ethnovetweb.com.

[235] S. Talalaj and A. Czechowicz, "Hazardous herbal remedies are still on the market," Medical Journal of Australia, vol. 153, no. 5, p. 302, 1990.

[236] D. V. C. Awang, "Maternal use of ginseng and neonatal androgenization," JAMA: The Journal of the American Medical Association, vol. 265, no. 14, 1828 pages, 1991.

[237] D. P. Waller, A. M. Martin, N. R. Farnsworth, and D. V. C. Awang, "Lack of androgenicity of Siberian ginseng," JAMA: The Journal of the American Medical Association, vol. 267, no. 17, 2329 pages, 1992.
[238] P. Golightly, "Herbal products and breastfeeding," ALCA News, vol. 7, no. 1, 1996.

[239] R. S. Horowitz, K. Feldhaus, R. C. Dart, F. R. Stermitz, and J. J. Beck, "The clinical spectrum of Jin Bu Huan toxicity," Archives of Internal Medicine, vol. 156, no. 8, pp. 899-903, 1996.

[240] D. V. C. Awang, Tyler's Herbs of Choice: The Therapeutic Use of Phytomedicinals, CRC Press, 3rd edition, 2009.

[241] J. Newman, "How breast milk protects newborns.", Scientific American, vol. 273, no. 6, pp. 76-79, 1995.

[242] R. Tisserand and T. Balacs, Essential Oil Safety, Churchill and Livingstone, London, UK, 1995.

[243] Fielding D., "Ethnoveterinary medicine in the tropics - key issues and the way forward? Scottish Branch Workshop," in Proceedings of the Durham Conference on Indigenous Knowledge in Tropical Agriculture Research and Development, Centre for Tropical Veterinary Medicine, Royal (Dick) School of Veterinary Studies, The University of Edinburgh, Midlothian, Scotland, 1998.

[244] M. Tafara and M. B. Taona, "Ethnoveterinary medicine: a potential alternative to orthodox animal health delivery in Zimbabwe," International Journal of Applied Research in Veterinary Medicine, vol. 2, no. 4, pp. 269-273, 2004.

[245] V. P. Belsare, S. K. Raval, and P. R. Patel, "Importance of indigenous knowledge of animal husbandry for development, Selected Papers. File 3 of 9: Part 2," in Ethnoveterinary Medicine: Alternatives for Livestock Development. Proceedings of an International Conference on Validation of Ethnoveterinary Medicine held on November 4-6, 1997, MDMTC, Pune, India, E. Mathias, D. V. Rangnekar, and C. M. McCorkle, Eds., vol. 1, BAIF Development Research Foundation, Pune, India, 1998.

[246] SK. Hamed, "Traditional veterinary practices in rural Medak of Andhra Pradesh, File 3 of 9: Part 2. in. Ethnoveterinary Medicine," in Ethnoveterinary Medicine: Alternatives for Livestock Development. Proceedings of an International Conference on Validation of Ethnoveterinary Medicine held on November 46, 1997, MDMTC, Pune, India, E. Mathias, D. V. Rangnekar, and C. M. McCorkle, Eds., vol. 1, Pune, India, BAIF Development Research Foundation, 1998. 


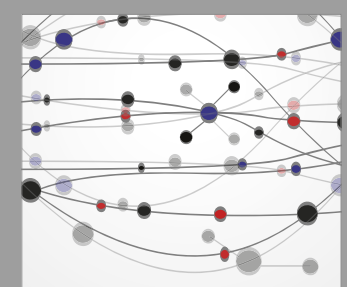

The Scientific World Journal
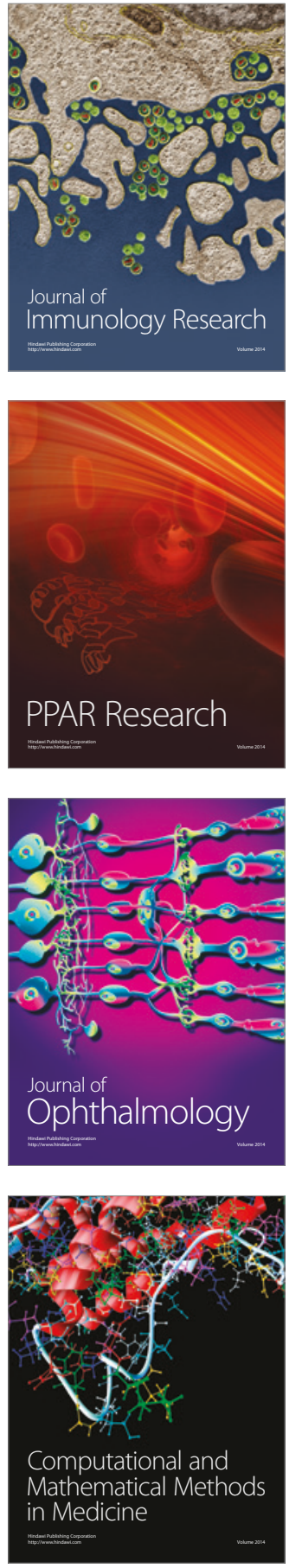

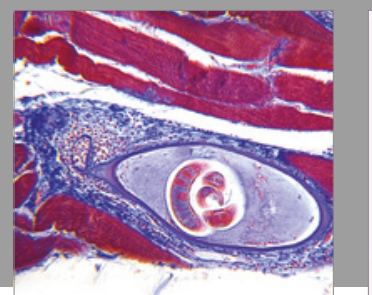

Gastroenterology Research and Practice
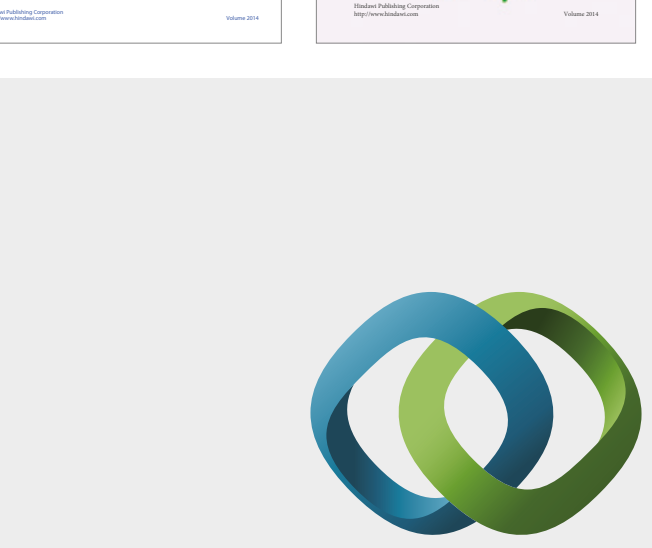

\section{Hindawi}

Submit your manuscripts at

https://www.hindawi.com
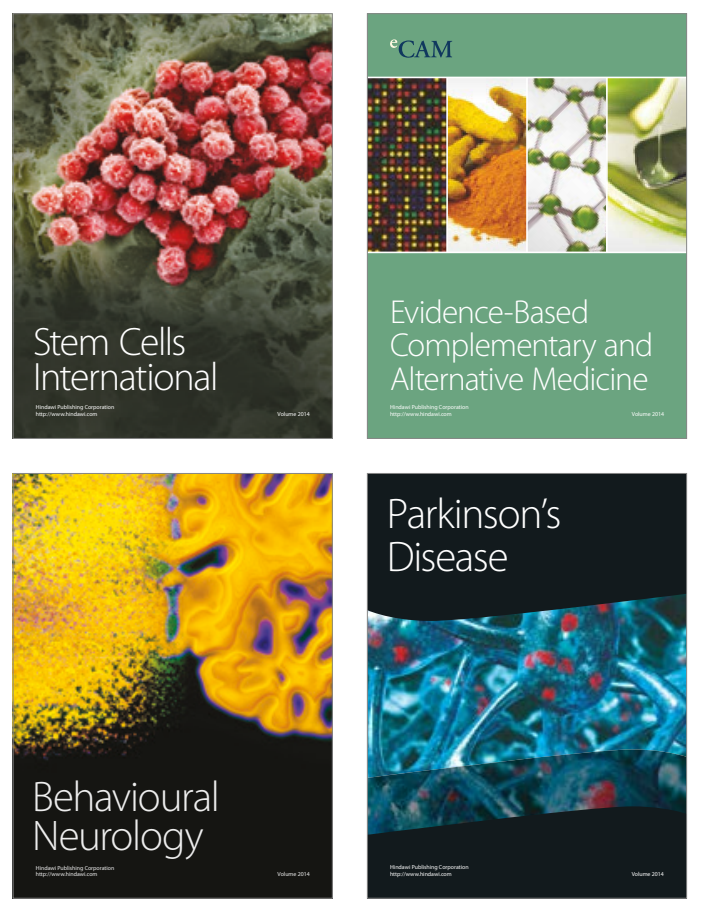
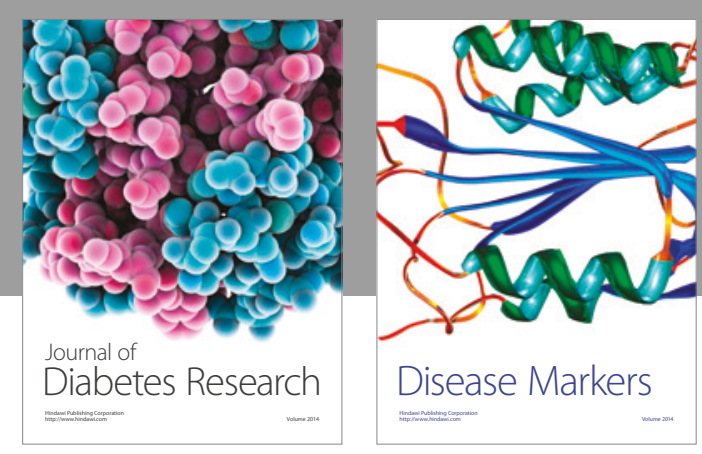

Disease Markers
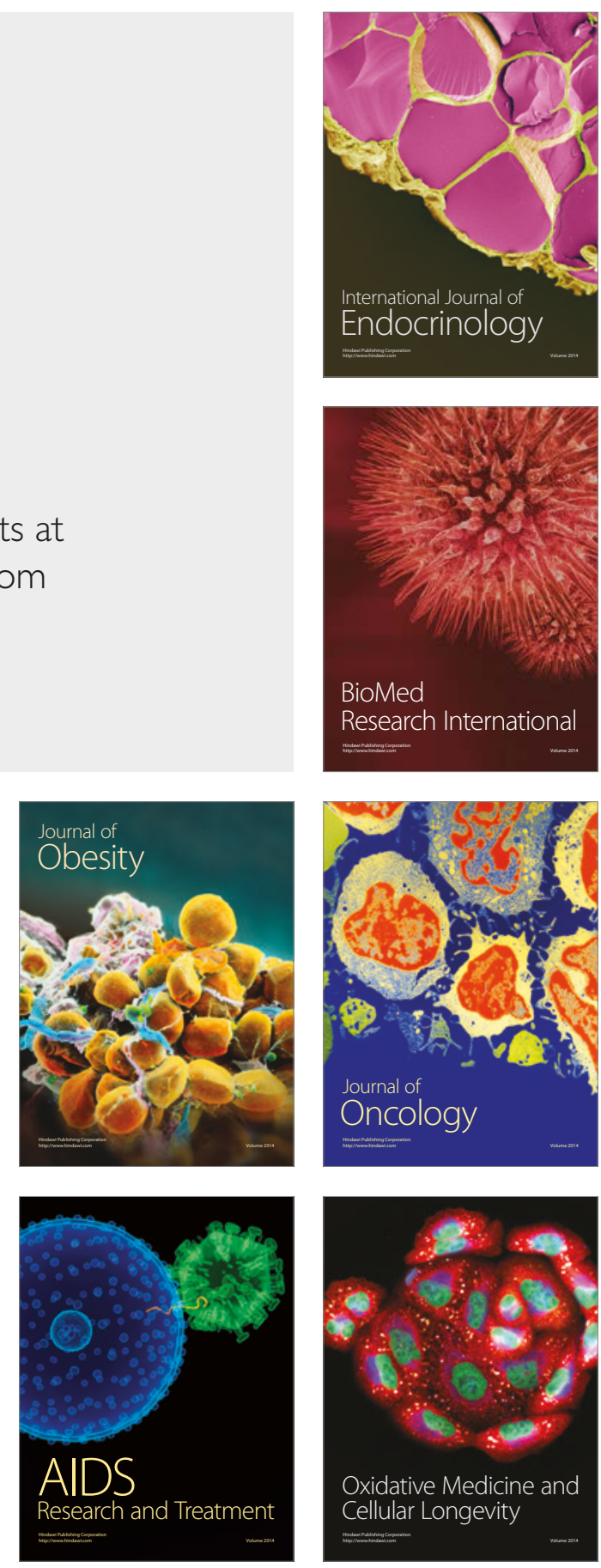